\title{
Managing Foreign Exchange Revenues with the Aim of Simultaneous Preservation of Production Competitiveness and Inflation Control: A Review of China's Experience
}

\author{
Zahra Kaviani $^{1}$ \\ Seyed Mahdi Barakchian² | barakchian@sharif.ir
}

\begin{abstract}
China has experienced a substantial surplus in its balance of payments since 2000 . Based on China's law, its central bank buys the balance of payments' surplus. This action, along with the closed capital accounts, can lead to an increase in the bank's foreign asset and consequently raise the monetary base and cause inflation. This paper shows that the Central Bank of China has been successful in keeping the inflation level low through sterilization of foreign assets in a transition period when a huge surplus in the balance of payments could lead to a severe increase in the monetary base. By issuing bonds and increasing the rate of banks' required reserves, the Central Bank of China has been able to manage the incoming foreign reserves and control the growth of liquidity and monetary base. As a matter of fact, this policy has been successful in restraining the rise in the value of home currency and inflation at the same time. Afterwards, during the smooth period of the monetary base growth (the 2010s), due to inflated monetary base at the end of the transition period, the balance of payments' surplus does not lead to a sharp increase in the monetary base anymore; therefore, bond issuing policies and raising the rate of banks' required reserves are not utilized like before.
\end{abstract}

Keywords: Monetary Policy, Sterilized Intervention, Currency Boom, China, Required Reserve Rate.

JEL Classification: F31, E52, E51.

1. Ph.D. Student in Economics, Institute for Management and Planning Studies, Tehran, Iran.

2. Assistant Professor in Economics, Faculty of Management and Economics, Sharif University of Technology, Tehran, Iran (Corresponding Author). 


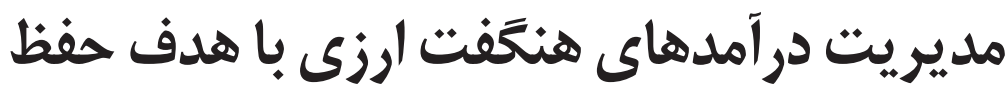 رقابتيذيرى توليد و كنترل تورم بله صوريت

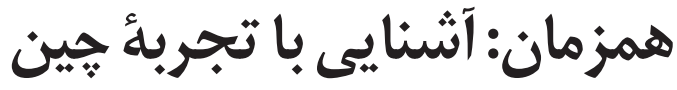

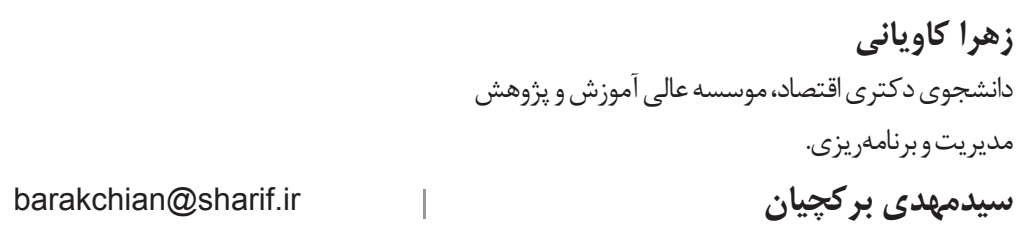

استاديار اقتصاد دانشكده مديريت و اقتصان دان دانشعاه صنعتى شريف (نويسنده مسئول).

نوع مقاله: ترويجى

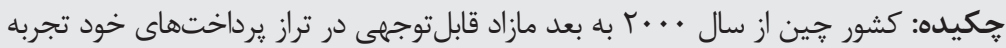

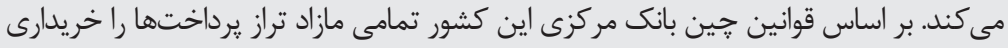

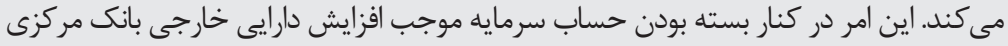

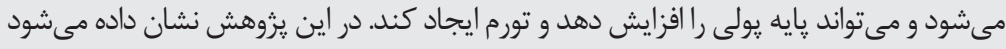

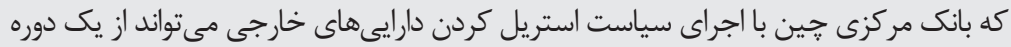

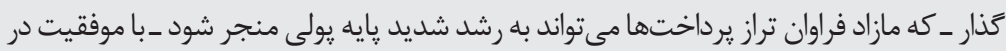

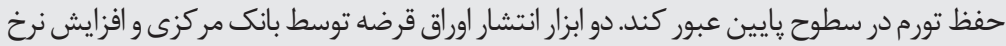

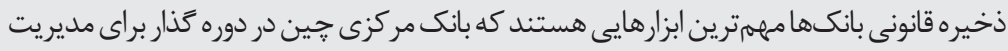

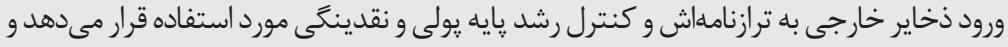

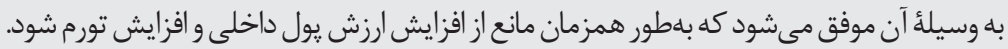

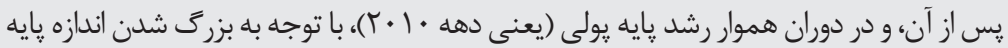

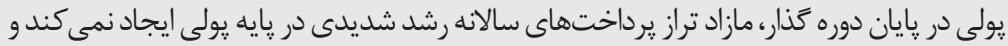

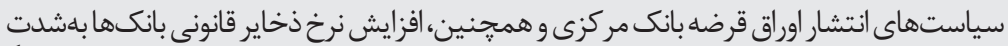

كذشتهاستفادهنمىشوند.

كليدوازهها: سياست يولى، دخالت استريلشده، رونق ارزى، سياست ارزى، جين، نرخ ذخيره قانونى. طبقهبندى E51, E52, F31:JEL. 
درآمدهاى ارزى علاوه بر اينكه توانايى يك كشور را براى تامين نيازهايش از راه واردات افزايش مى دهد، سبب مىشود آن كشور بتواند نقش بيشترى در معادلههاى اقتصادى جهانى بازى كند.

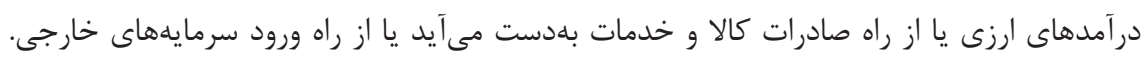

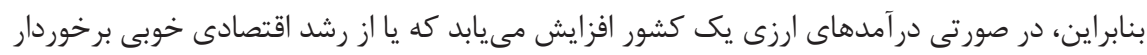

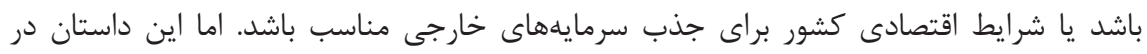

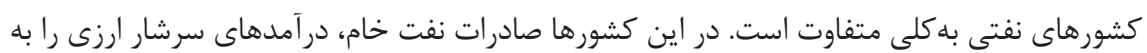

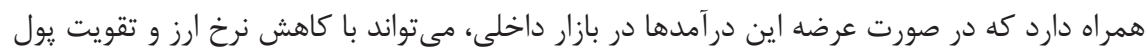

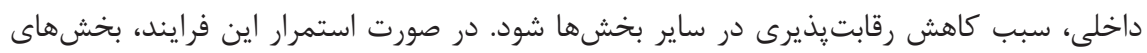

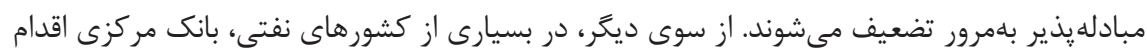

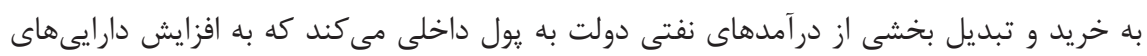

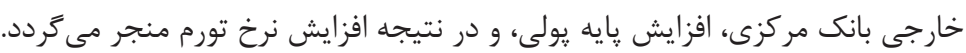

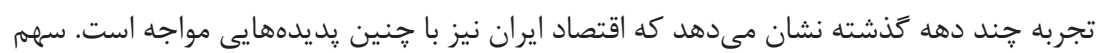

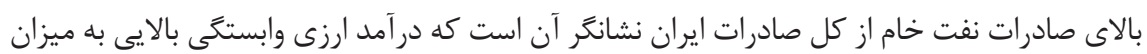

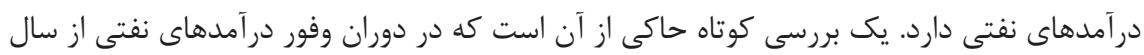

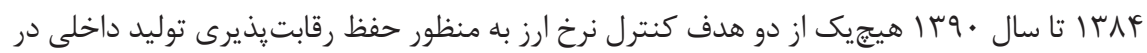
مقابل توليد خارجى، و كنترل تورم به منظور حفظ ثبات در محيط اقتصاد كلان محقق نشده است.

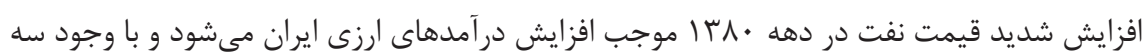

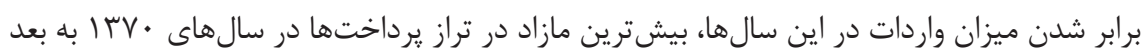

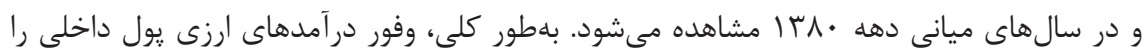

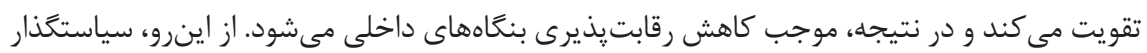

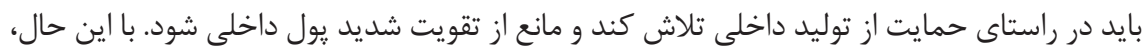

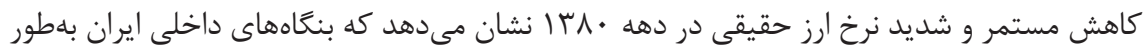

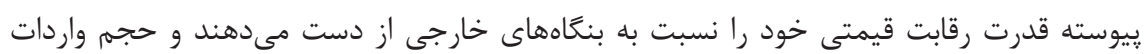

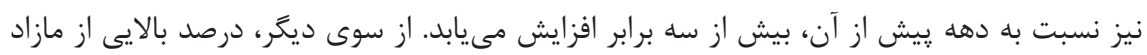

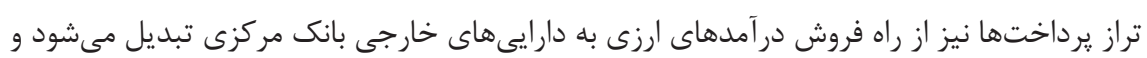


بدون آن كه از سمت بدهىهاى بانك مركزى كنترل شود، بهطور مستقيم به افزايش پايه يولى منجر

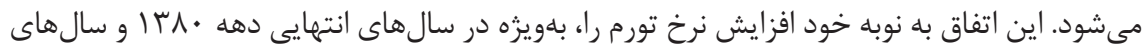

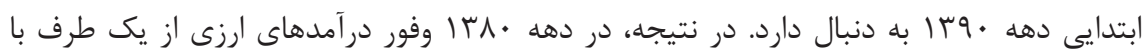

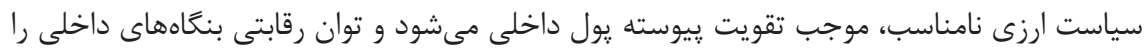

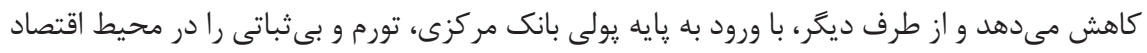

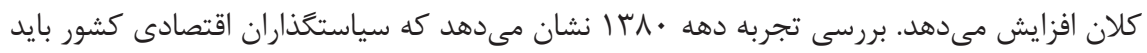

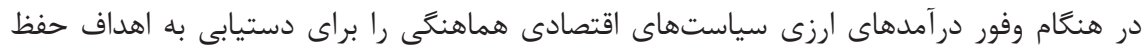
رقابتيذيرى توليد داخلى و كنترل تورم به صورت همزمان بكار كيرند. كشورهاى متعددى دارى دارى مازاد تراز يرداختها هستند و يك تجربه رايج در خصوص كنترل درآمدهاى ارزى در دور دورههاى وفور

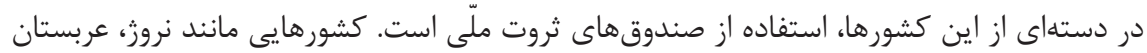
سعودى، و شيلى از جمله كشورهاى صادركننده منابع طبيعى هستند كه با استفاده از صندوق ثروت

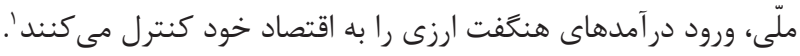

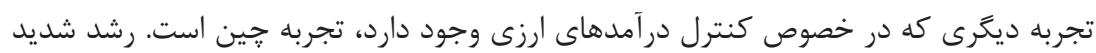

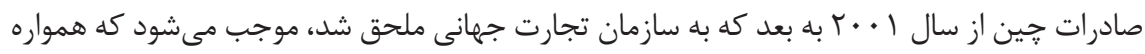
در جهت جلوگيرى از تقويت قابلتوجه يول داخلىاش تلاش كند. به همين منظور، بانكى مركزى جين

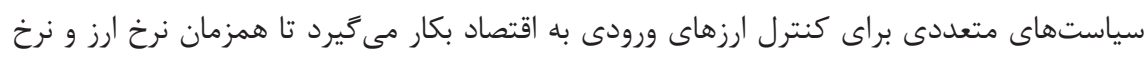
تورم را كنترل كند. اين يروهش به بررسى تجربه جين در كنترل نرخ ارز و نرخ تورم به هنعام وفور

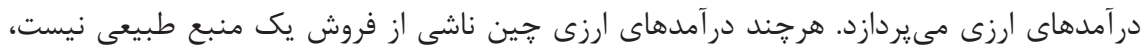

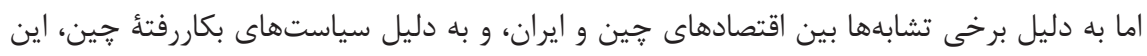

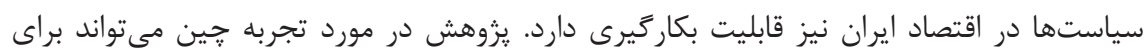

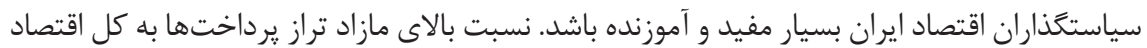
(يعنى توليد ناخالص داخلى)، در هر دو كشور جين و ايران از جمله ويزگگىهاى مشترك اين دو كشور

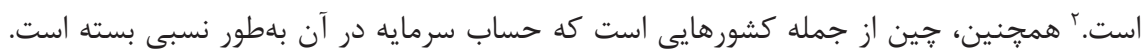

ا. بر اساس آخرين ردهبندى موسسه صندوقهاى ثروت (https:/www.swfinstitute.org/)، به لحاظ ميزان

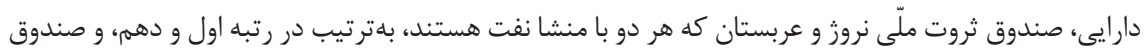
ثروت شيلى با منشا مس در رتبه جهلم دنيا قرار دارد.

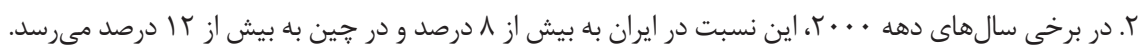


بدين معنا كه بنگاهها و خانوارها براى نتحهدارى و سرمايه گذارى ارز خارجى با محدوديت مواجه هستند

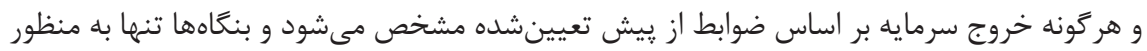
واردات مىتوانند ارز خريدارى كنند. در ايران نيز هرجند ضوابطى براى ورود و خروج ارز، كه به بسته

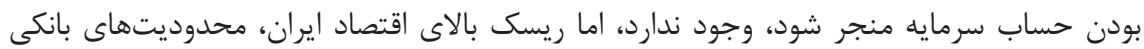
ناشى از شرايط تحريم، و تبعيت نكردن نظام بانكدارى ايران از استانداردهاى روز جهانى باعث مى شى بـند

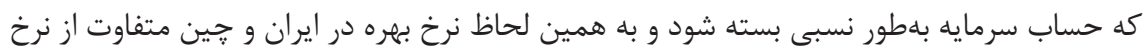

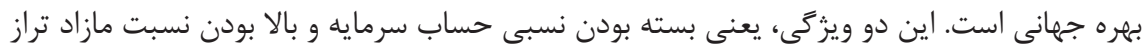

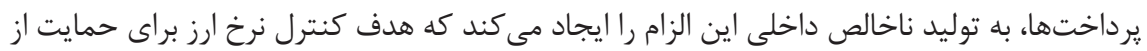

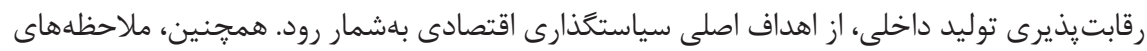

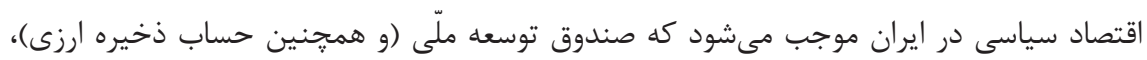
از كاركرد اصلى خود تا حدودى فاصله بخيرد و نقش كنترل ورود درآمدهاى ارزى به داخل اقتصاد

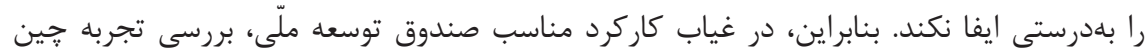

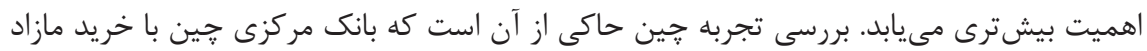
تراز يرداختها مانع از افزايش ارزش يوآن در مقابل دلار و ساير ارزهاى خارجى مىشى لرد. اين اقدام،

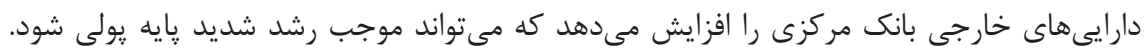

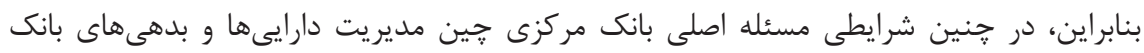

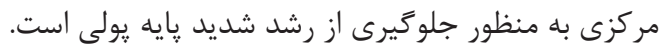
در اين يزوهش نشان داده مىشود كه بانك مركزى جين با انتشار اوراق قرضه بانك مركزى، و و

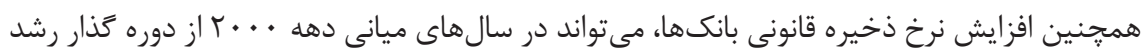

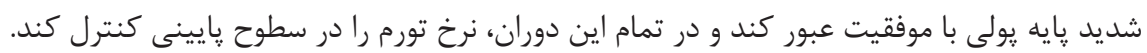

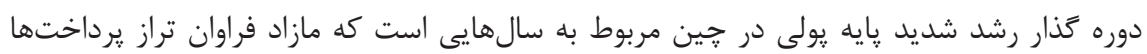

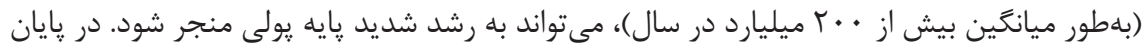

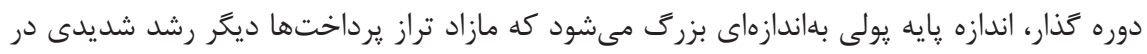

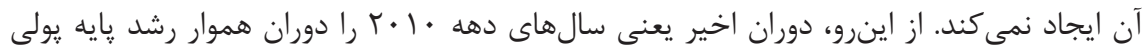
نامگذارى مى كنند. در واقع، در سالهاى دوره كذار حجم بالايى از اوراق قرضه بانك مركزى منتشر و

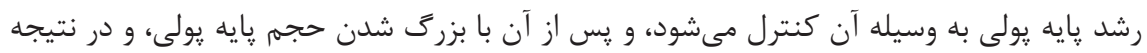

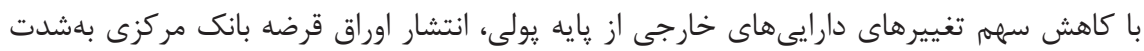




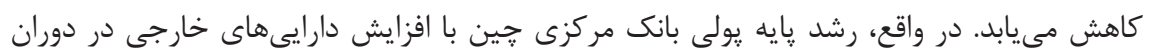

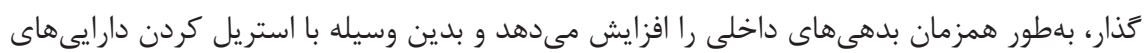

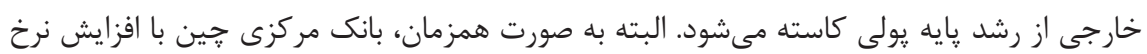

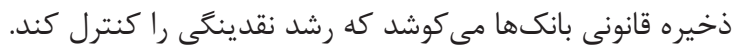

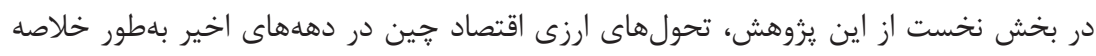

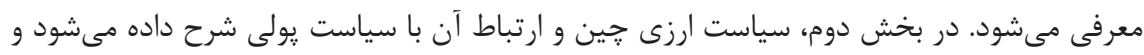

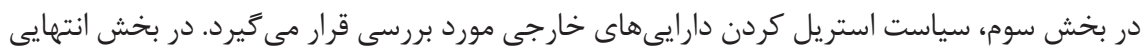
نيز بحث و نتيجه كيرى ارائه مى كردد.

اقتصاد جين از اوايل دهه • •191 به سمت آزادسازى و ارتباطات كسترده با اقتصاد جهانى يِيش

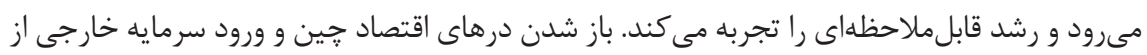

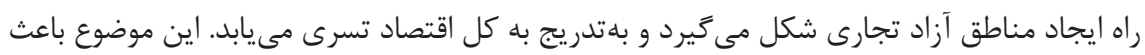

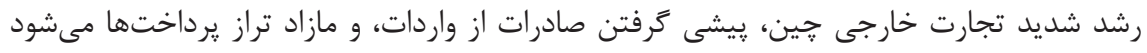

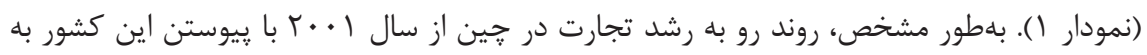

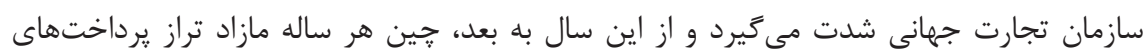

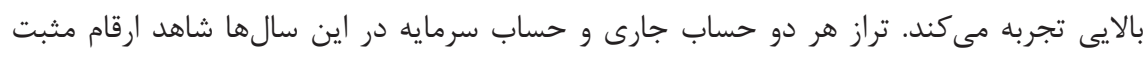

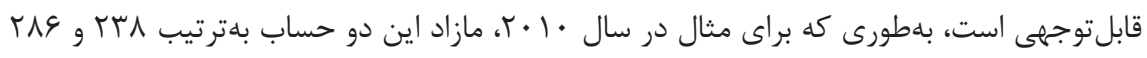

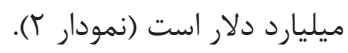




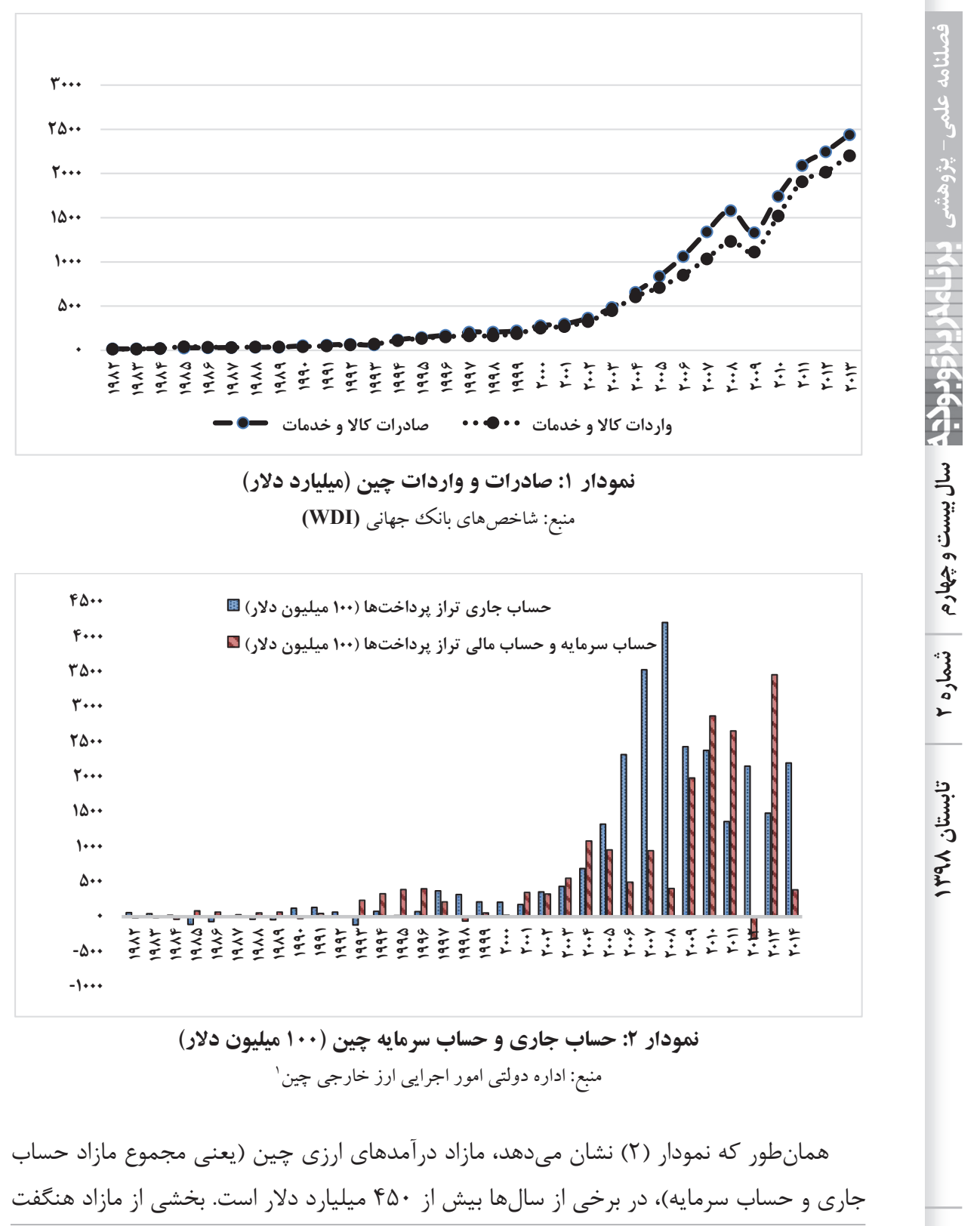

1. State Administration of Foreign Exchange 
تراز يرداختها از سياستهاى ارزى جين مبنى بر دخالت در بازار ارزهاى خارجى براى ارزان نكَه

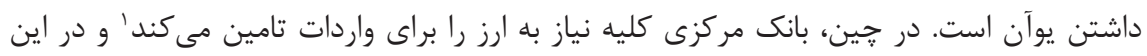

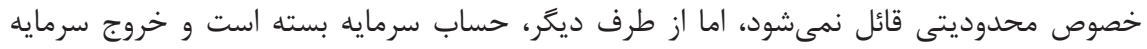

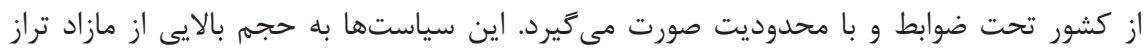

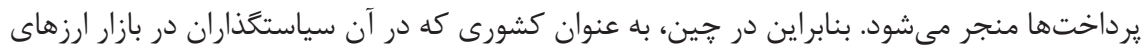

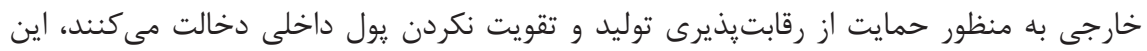

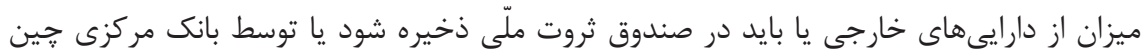

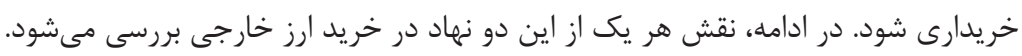

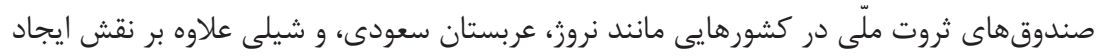

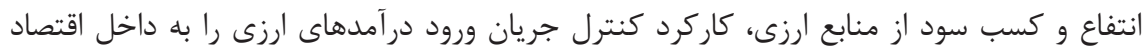

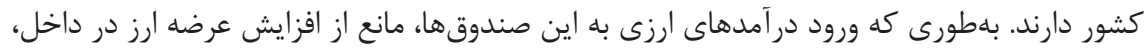

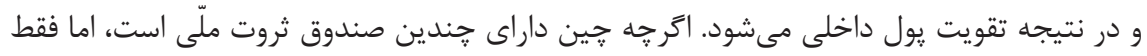

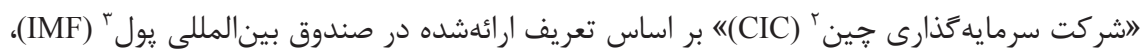

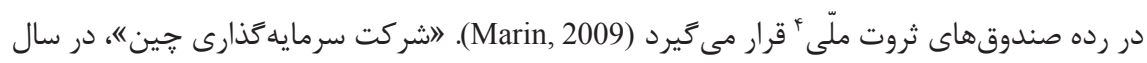

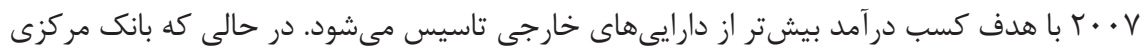

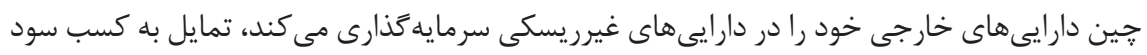

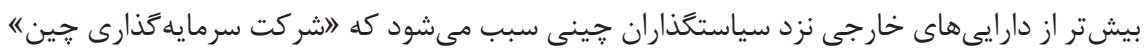

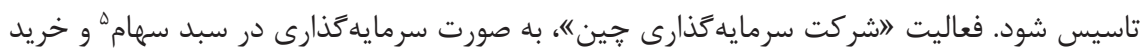

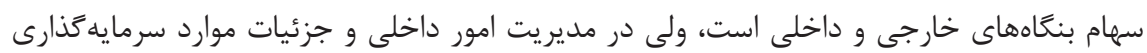

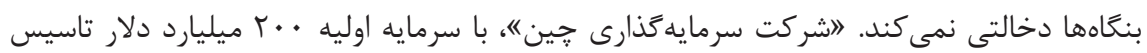

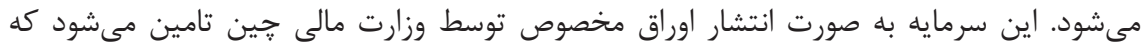

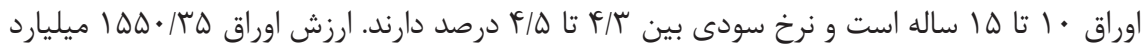

ا. بر اساس قوانين جين، هر گونه درآمد ارزى ناشى از صادرات و هركونه ورودى ارز خارجى توسط بانك مركزى

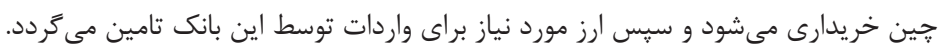

2. China Investment Corporation

3. International Monetary Fund (IMF)

119

4. Sovereign Wealth Fund (SWF)

5. Portfolio Investment 


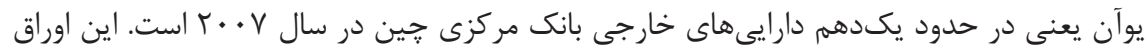

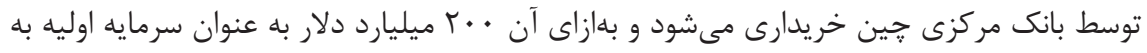

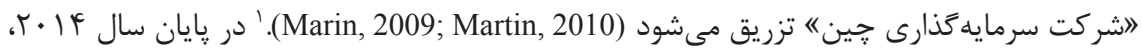

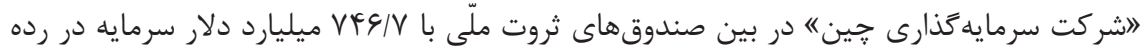

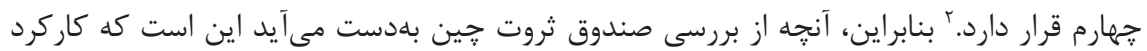

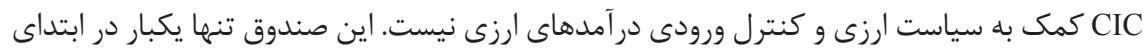

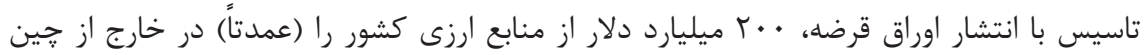

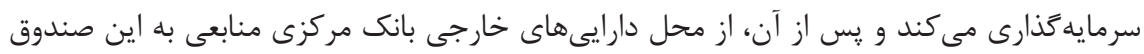

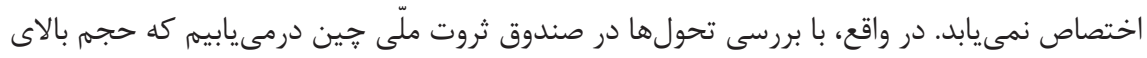
مازاد تراز يرداختها وارد اين صندوق نمىشود. يعنى برخلاف كشورهايى مانند نروز كه نقش صندوق

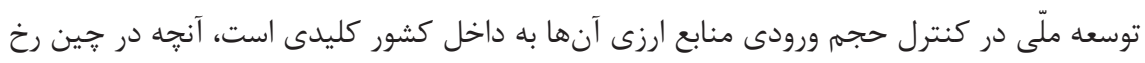
مىدهد اين است كه درصد بالايى از مازاد تراز يرداختها توسط بانكى مركزى خريد خريدارى مى بـشود و وارد دار ايى هاى خارجى بانك مركزى مىشود. باطورى كه نسبت تغييرهاى دارايىهاى خارجى بانك مركزى به مازاد تراز يرداختها در سالهاى مختلف بيش از •و درصد است (نمودار بَ).

1. بانك مركزى קين شركت 》هايجين مركزى" (Central Huijin) را به ارزش دفترى •V ميليارد دلار به

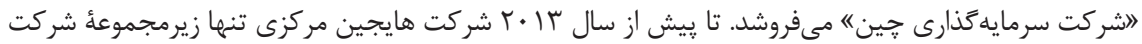

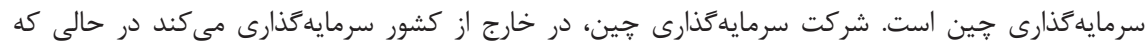

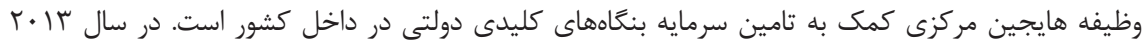

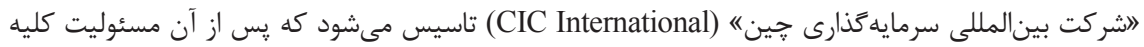

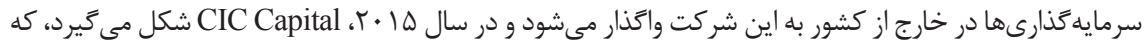

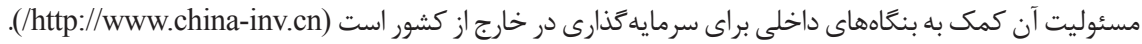
2. http://www.swfinstitute.org 


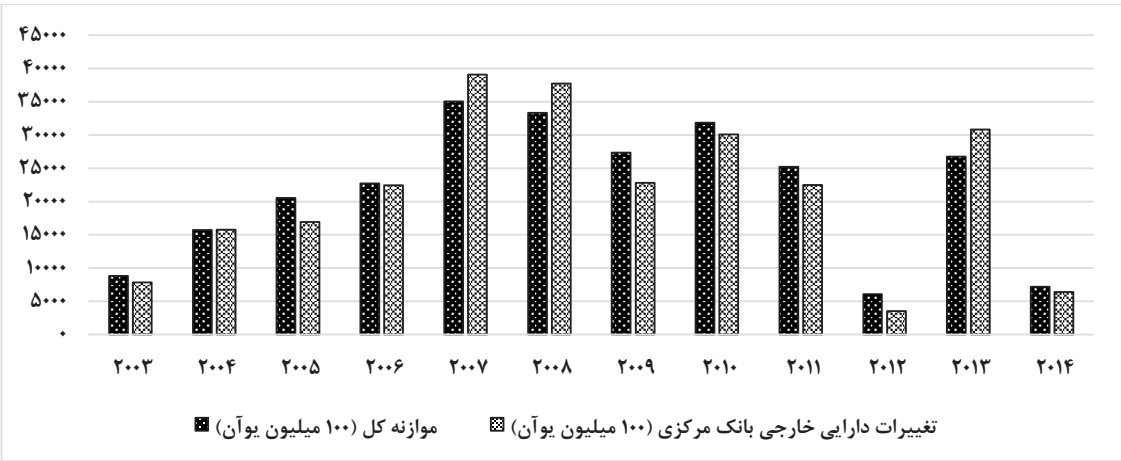

نمودار بّ: موازنه كل (مازاد تراز برداختها)، و تغييرهاى خالص دارايىهاى خارجى بانك مر كزى جين (·• ( ميليون يوآن)

$$
\text { منبع: اداره دولتى امور اجرايى ارز خارجى خين }
$$

خريد مازاد تراز يرداختها توسط بانك مركزى جين، موجب انباشت دارايىهاى خارجى بانك

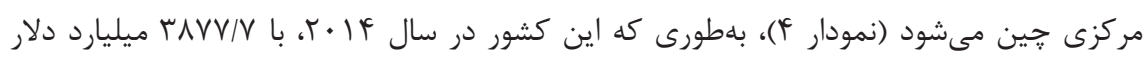

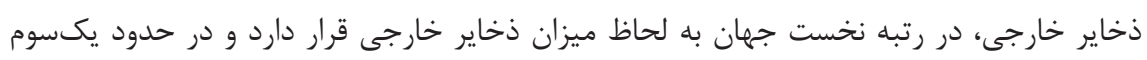
ذخاير خارجى دنيا را به خود اختصاص مى دهد دهد (نمودار ه).

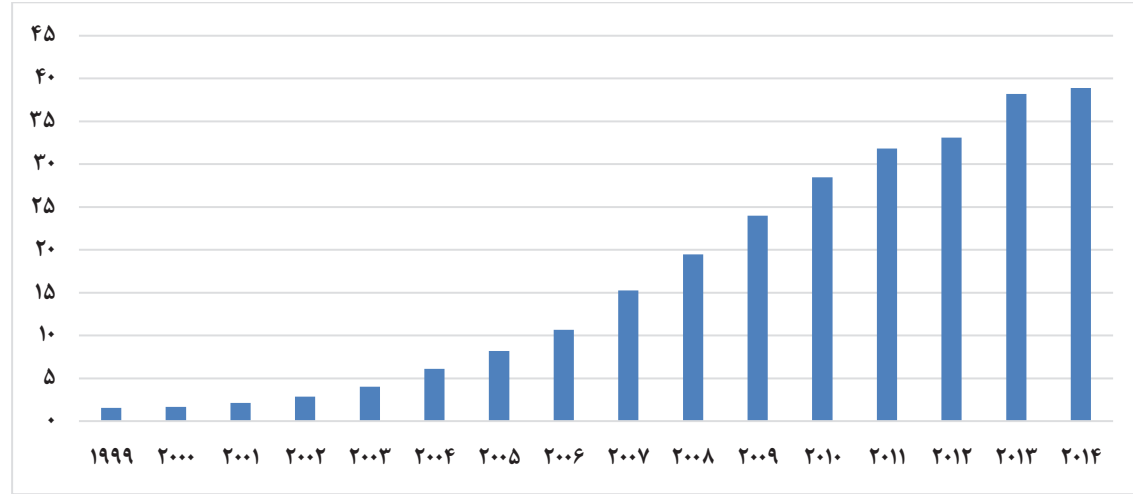

$$
\begin{aligned}
& \text { نمودار با: ذخاير خارجى جين ( • •ا ميليارد دلار) }
\end{aligned}
$$

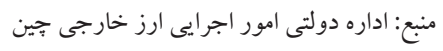




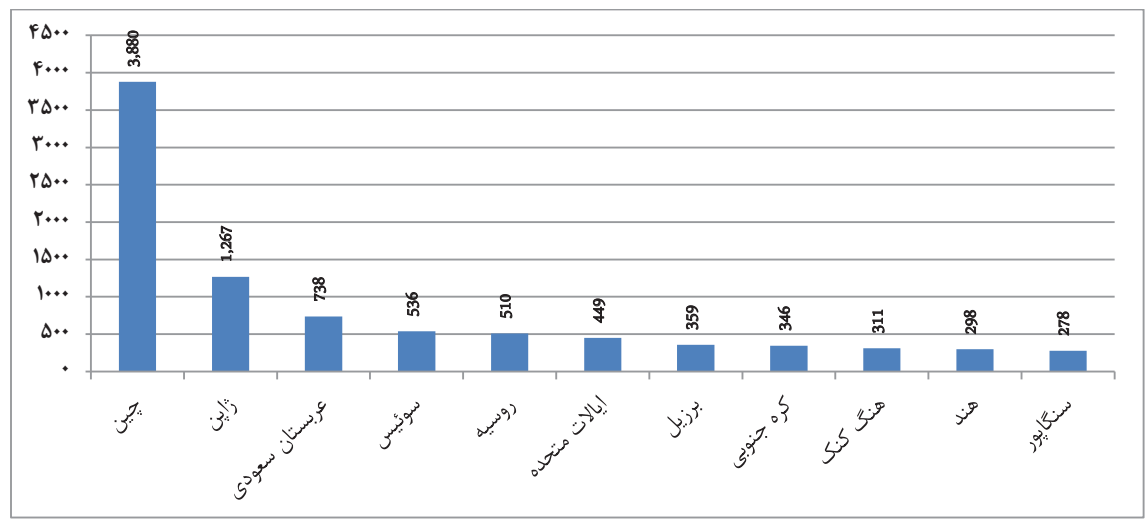

نمودار ه: ذخاير خارجى كشورهاى جهان در سال با.† (ميليارد دلار)

منبع: شاخص هاى بانك جهانى (WDI)

اين دارايىهاى خارجى در سمت دارايىهاى ترازنامه بانك مركزى جين قرار دارند و موجب

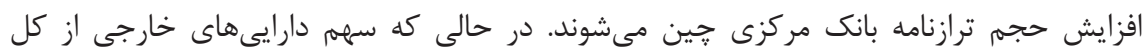

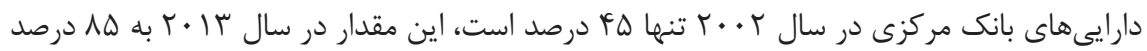

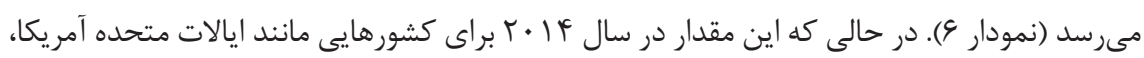

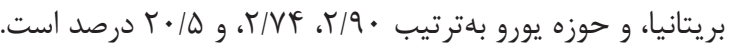




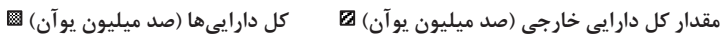

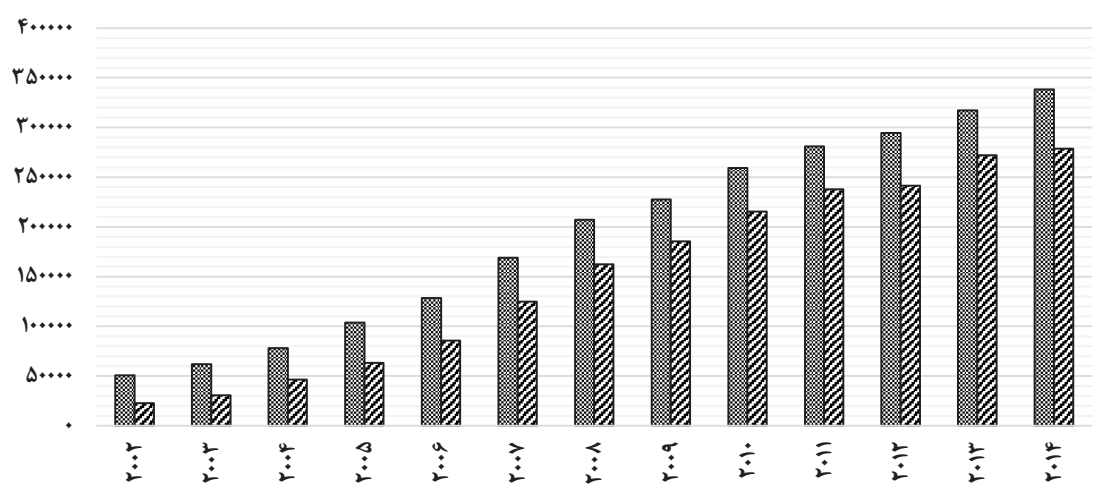

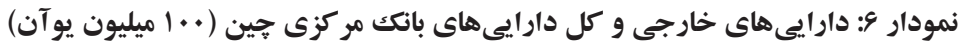
منبع: ترازنامه بانك مركزى جين، سالهاى مختلف

بنابراين بانك مركزى جين به منظور حمايت از توليد داخلى در بازار ارزهاى خارجى دخالت

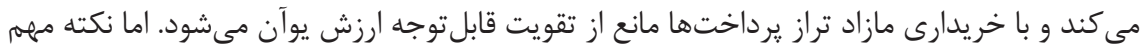
در اينجاست كه در اثر اين سياست، دارايى هاى خارجى بانك مركزى افزايش مىيابد كه ميىتواند به به

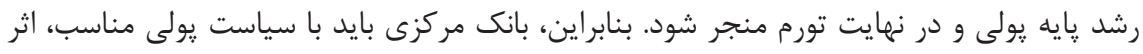
رشد دارايى هاى خارجى را در ترازنامه اين بانك خنثى كند. اين نوع دخالت در بازار ارزهاى خارجى، دخالت استريلشده ن نام دارد كه در نمودار (Y)، به صورت نمودارى بَ نمايش داده مىشود.

1. دسترس در وبسايت بانك مركزى جين به آدرس اينترنتى:

http://www.pbc.gov.cn/publish/english/963/index.html 


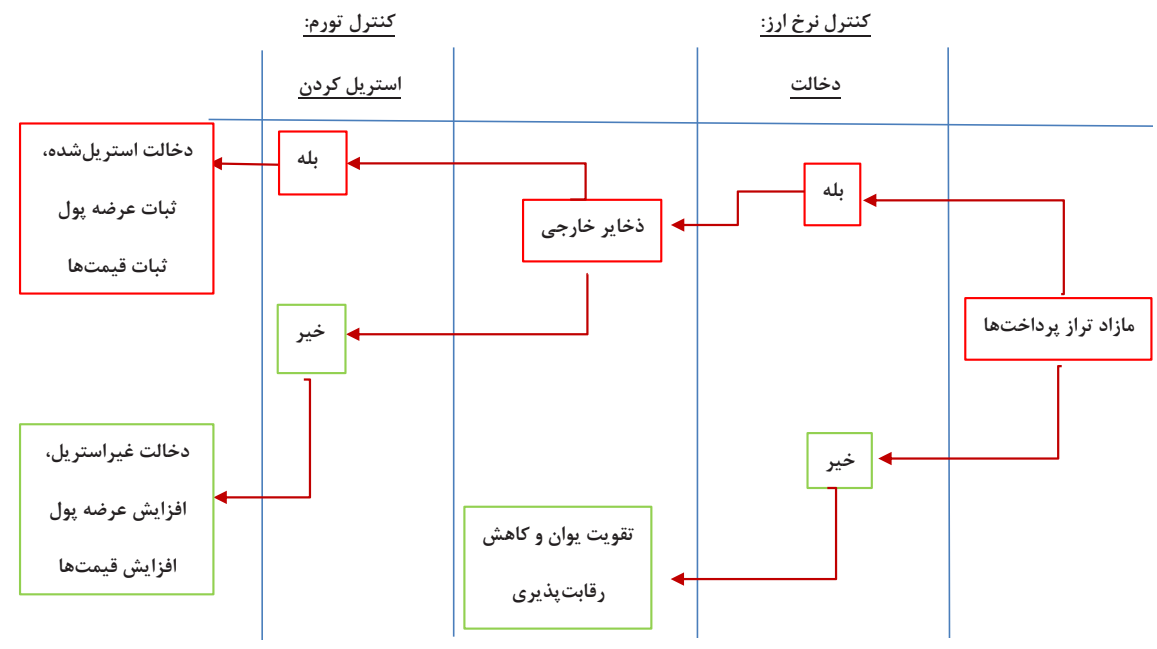

نمودار \: دخالت استريلشده در بازار ارزهاى خارجى

در بخش بعد، به بررسى سياستهاى جين براى دخالت استريلشده در بازار ارزهاى خارجى به

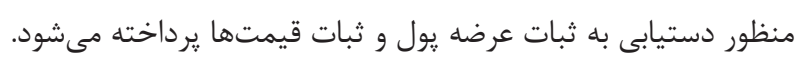

سياست دخالت استريلشده در بازار ارز به دو بخش سياست ارزى و سياست يولى تقسيم مىشود.

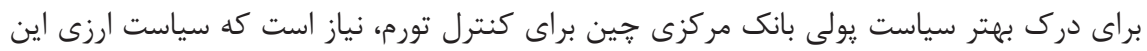

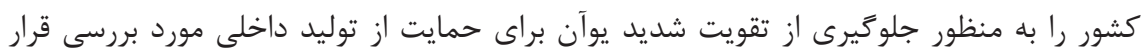

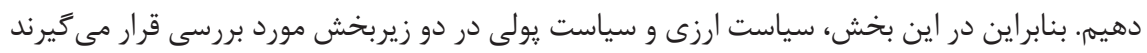
و در بخش بعدى، سياست استريل كردن دارايىهاى خارجى به تفصيل توضيح داده مىشود.

بلهور كلى، سياست ارزى جين پِ از آغاز آزادسازى اقتصادى به دو دوره زمانى تقسيم مىشود:'

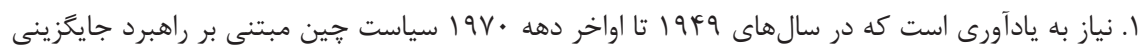

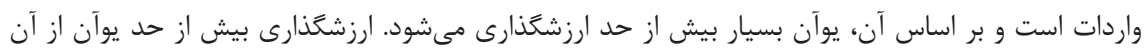


رسيدن جين به وضعيتى كه در اواسط دهه • •199 نرخ ارز آن بتواند بر اساس عرضه و تقاضا

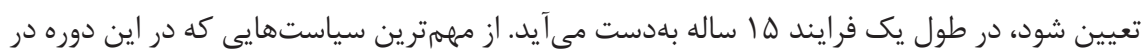

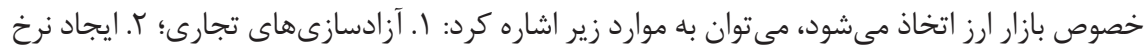

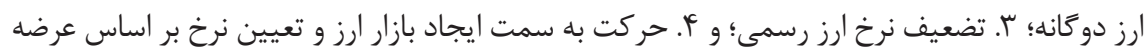

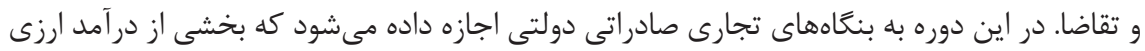

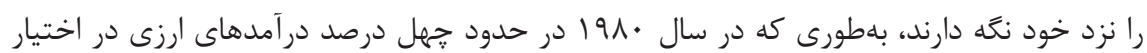

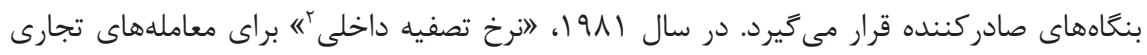
ايجاد مى شود، بلطورى كه تمامى معاملههاى تجارى با اين نرخ انجام مى شوند و معاملههاى غير تجارى

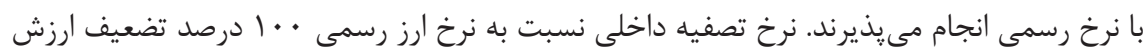

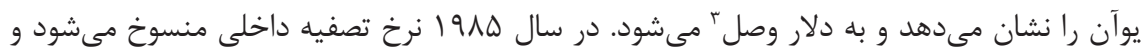

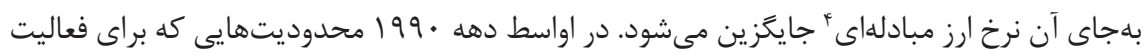

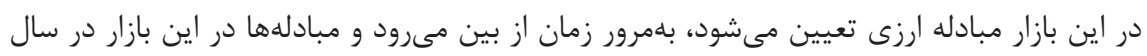

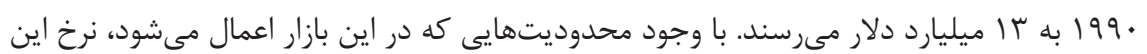

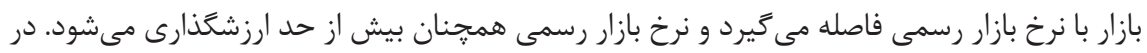

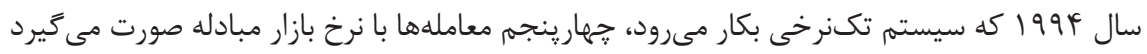

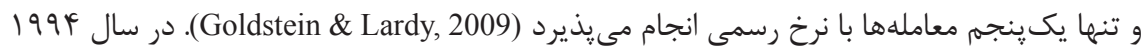

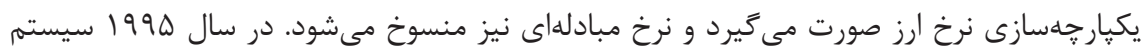

جهت است كه كالاهاى واسطهاى با قيمتى يايينتر از قيمت تعادلى وارد مىشوند و از طرف ديخر، تعرفه بالايى

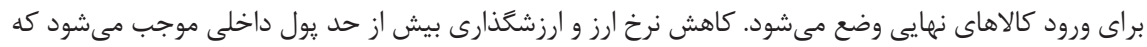

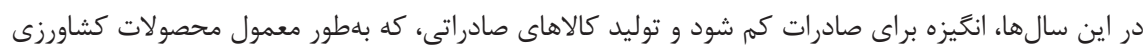

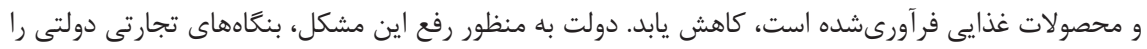

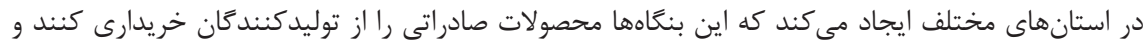
بلبور مستقل صادر كنند.

(. بيشتر مطالب از اين يزوهشها استخراج مىشود (Goujon \& Guérineau, 2006; Goldstein \& Lardy, 2009). 2. Internal Settlement Rate 
ارزى انكَهدارى' " كه بر اساس آن صادركنندكان مىتوانند درصدى از درآمدهاى ارزى را نزد خود

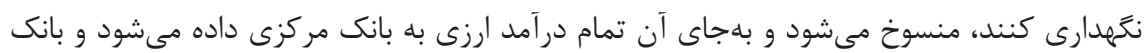

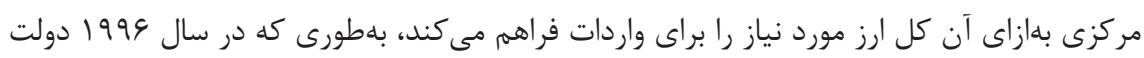

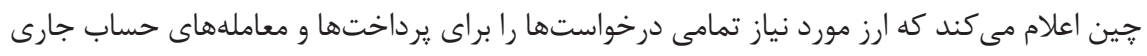

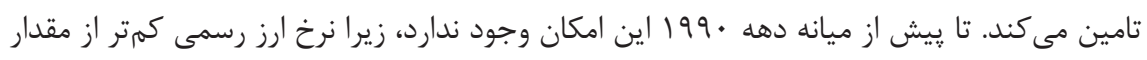

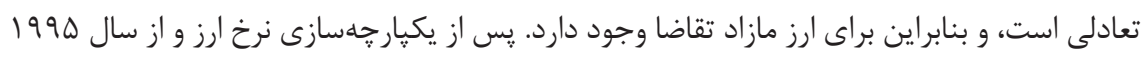

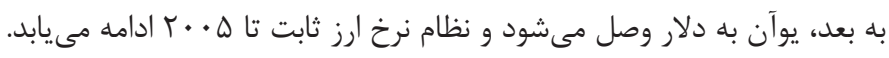

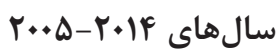

با گسترش تجارت جين و افزايش دارايىهاى خارجى اين كشور، بانك مركزى جين به منظور

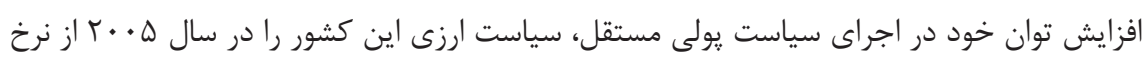
ارز ثابت، كه به دلار وصل است، به سياست ارزى شناور مديريتشده تغيير مىدهد. در اين سال

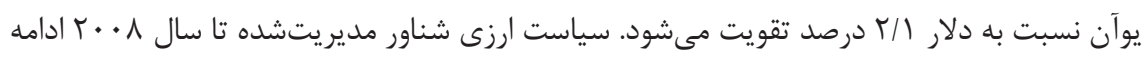

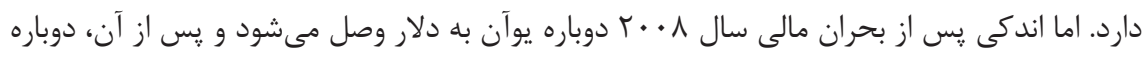

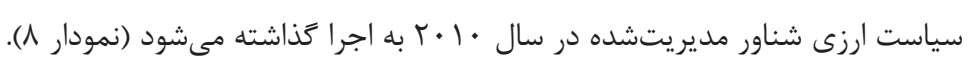




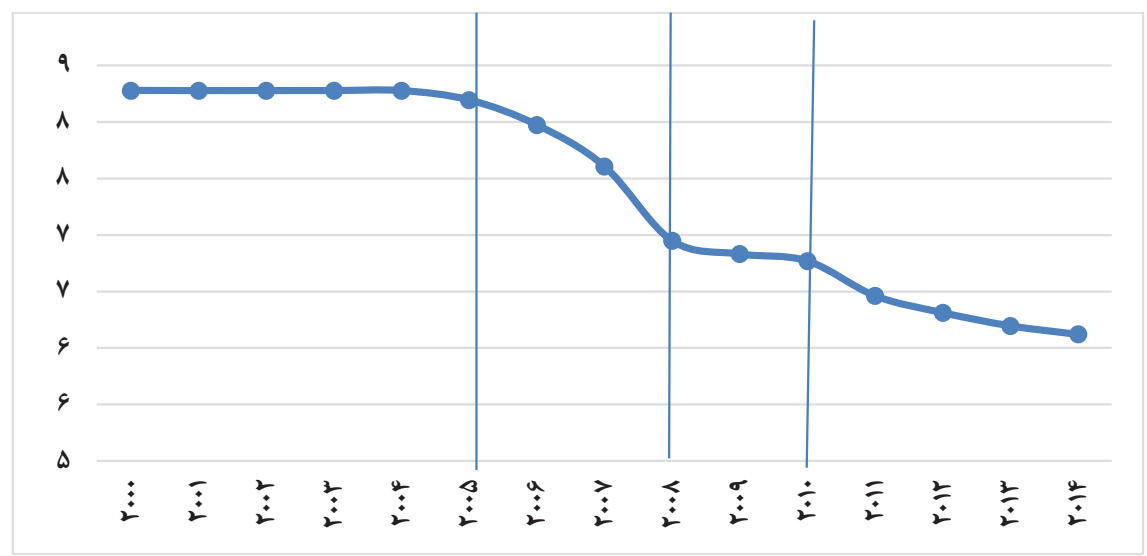

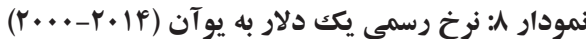

منبع: شاخصهاى بانكك جهانى (WDI)

رزيم كنونى نرخ ارز شناور مديريتشده در جين را مىتوان رزيم خزنده مبتنى بر سبد ارزى

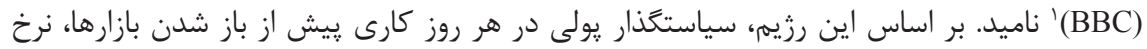

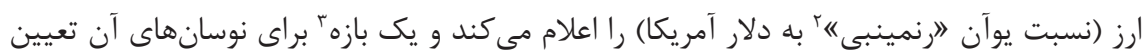

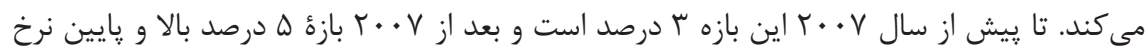
اعلامشده توسط بانك مركزى به عنوان محدوده مجاز نوسانهاى نرخ ارز در نظركرفته مى بـود. همجنين، با وجود آنكه سياستخذار يولى در خين نرخ يوآن را در مقابل دلار مديريت مى كند، اما

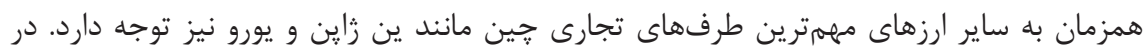

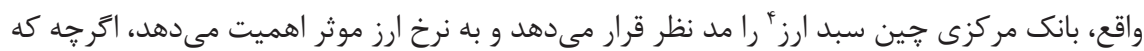
در اين سبد سهم دلار باطور قابلتوجهى بيشتر از ساير ارزهاست.

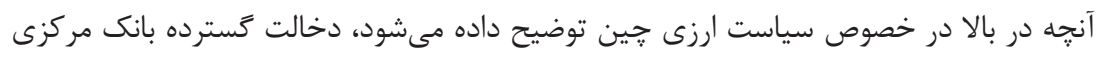
جين را در بازار ارز نشان مىدهد. اين موضوع باعث مىشود كه بانك مركزى مديريت همزمان بين

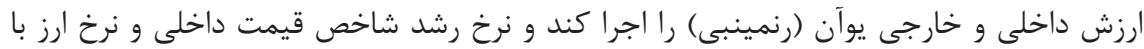

1. Band, Basket, \& Crawle Regime

2. Renminbi (RMB)

ITV

3. Band

4. Currency Basket 
يكديكر ارتباط معنادارى داشته باشند. بررسى دادهاى نرخ ارز و نرخ تورم در جين نشان مى دهد كه

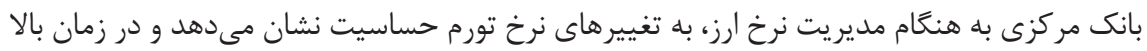

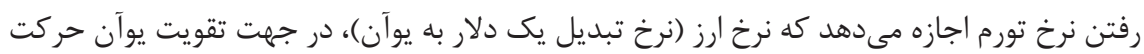

\section{كند تا از فشارهاى تورمى كاسته شود (نمودار 9).}

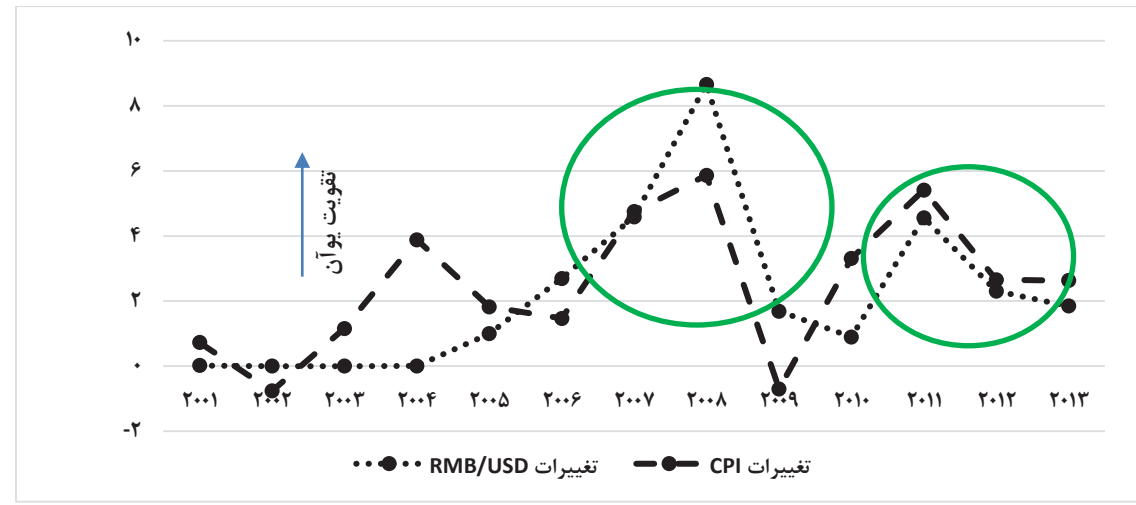

نمودار 9: نرخ تورم و نرخ تغييرهاى نسبت يوآن به دلار (درصد)

منبع: شاخص هاى بانك جهانى (WDI)

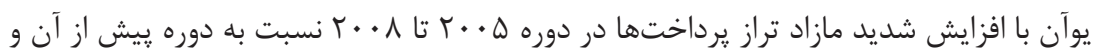

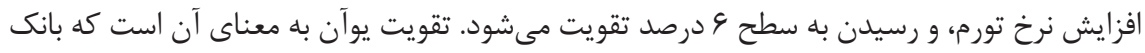
مركزى بازار ارزهاى خارجى را تا حدودى آزاد مى كند و در نتيجه، اندكى از فشار ترازنامهاى بانك

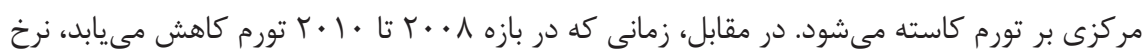
ارز نيز در اين دوران با وجود افزايش مازاد تراز يرداختها ثابت است و يوآن تقويت نمى شوده. يعنى

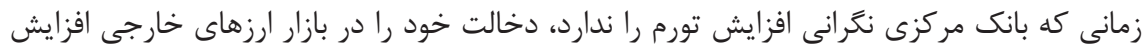

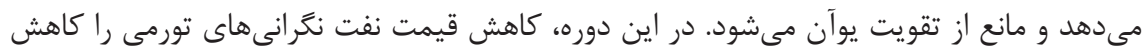
مىدهد و از طرف ديكر، بحران مالى در آمريكا موجب افت تقاضاى جهانى مى مى مود و سياستخذاران

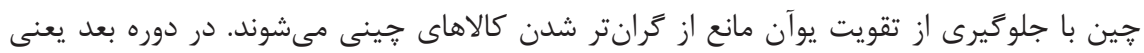

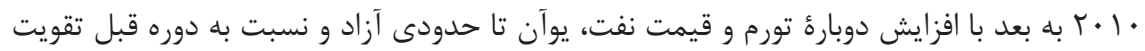

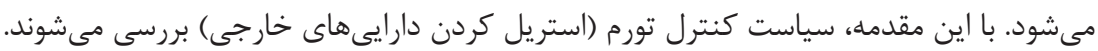




\section{سياست يولى جين (سياست استريل كردن)}

سياست يولى خين در قالب استريل كردن دارايىهاى خارجى و با هدف كنترل تورم در دهـ

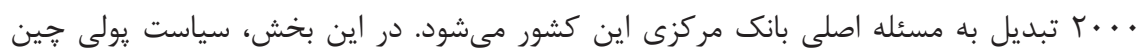

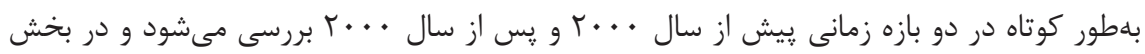

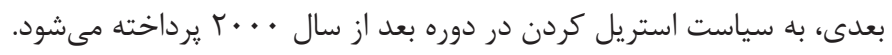

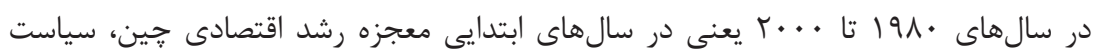

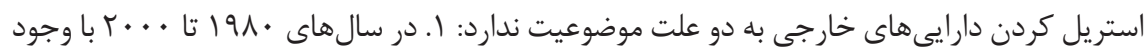
رشد تجارت خارجى و افزايش مازاد تراز يرداختها، اين مازاد به نسبت كل حجم اقتصاد در مقايسه

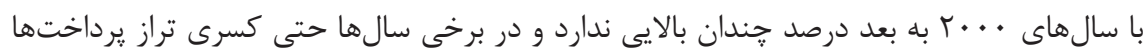

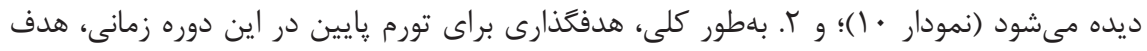

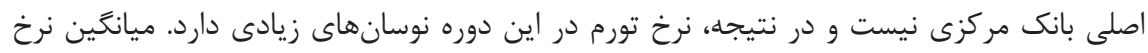

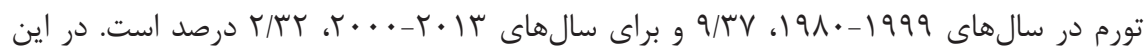
دوره و در سال F 199 نرخ تورم حتى به رقم FF درصد مىرسد و يس از آن است كه بانك مركزى

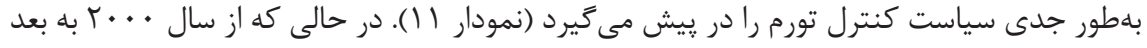

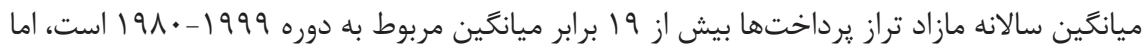

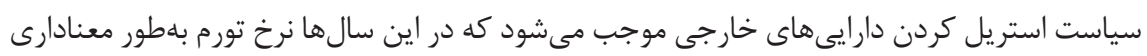
كمتر از دوره قبل باشد. 


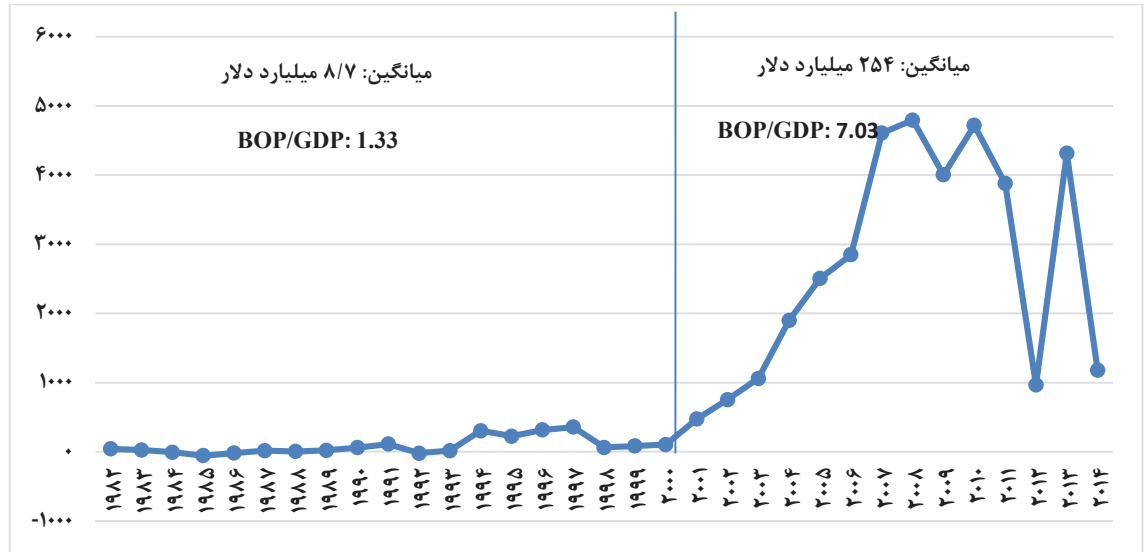

نمودار • ا: مازاد تراز برداختهاى جين ( •. 1 ميليون دلار)

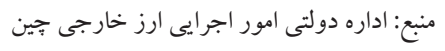

نمودار ا1: نرخ تورم جين (درصد)

منبع: شاخص هاى بانك جهانى (WDI) نورم جين (درص) 


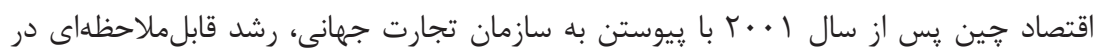

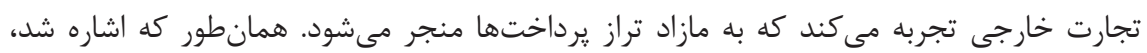
سياست ارزى جين در اين دوره معطوف به دخالت در بازار ارزهاى خارجى و جلوكيرى از تقويت شديد ارزش يول داخلى است كه به افزايش ذخاير خارجى و رشد دارايىهاى بانك مركزى منجر

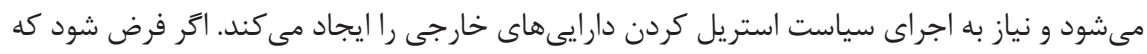

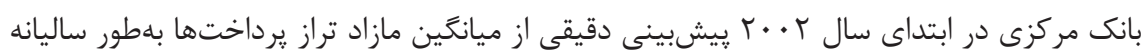

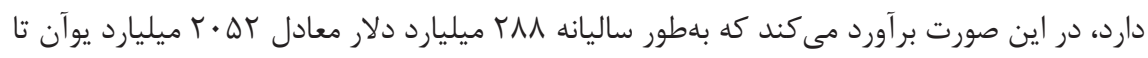

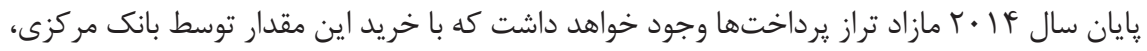

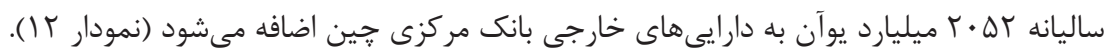

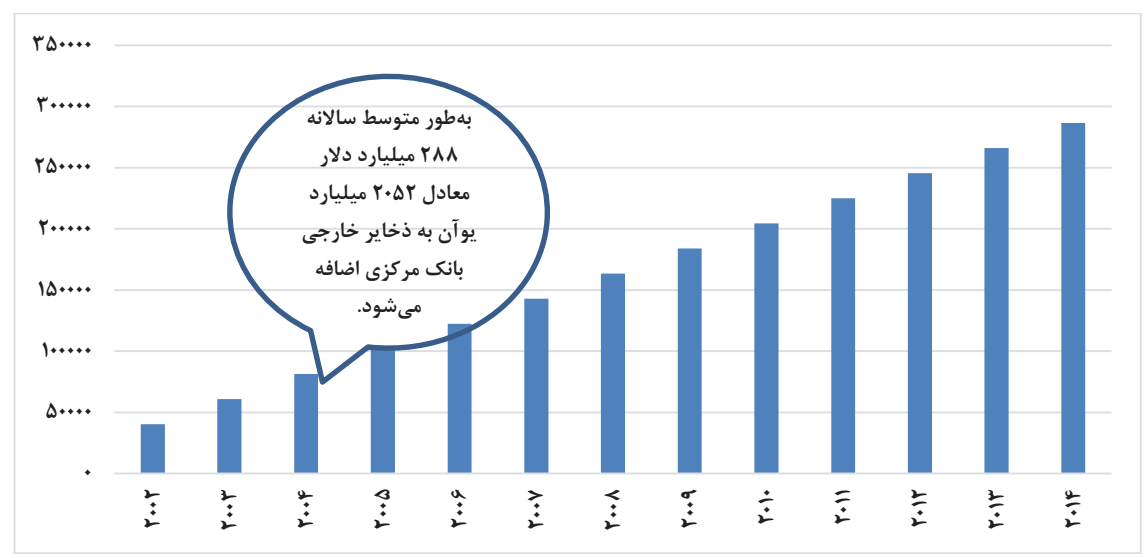

نمودار با ا: دارايى خارجى بر آوردشده (... ميليون يوآن)

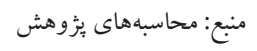

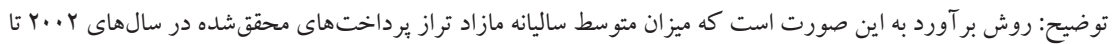

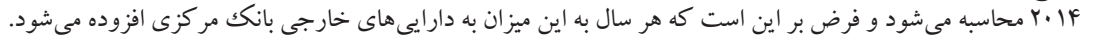

بنابراين، بانك مركزى جين با در اختيار داشتن اين اطلاعات برآورد خواهد كرد كه يايه يولى اين

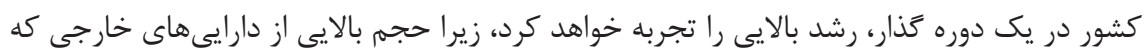

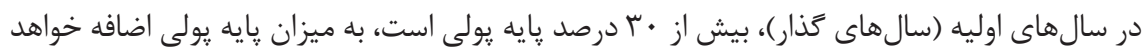




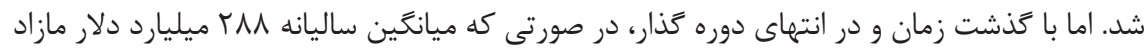
تراز يرداختها حفظ شود، اين مقدار نسبت به كل حجم يايه يولى (كه در طول زمان و در دوره گذار بهشدت رشد دارد)، داراى سهم پايين و در حدود 9 درصد است و از اينرو، رشد قابلتوجهى در پايه يولى ايجاد نمى كند و پايه يولى وارد دوره هموار رشد مىشود (نمودار س (1).

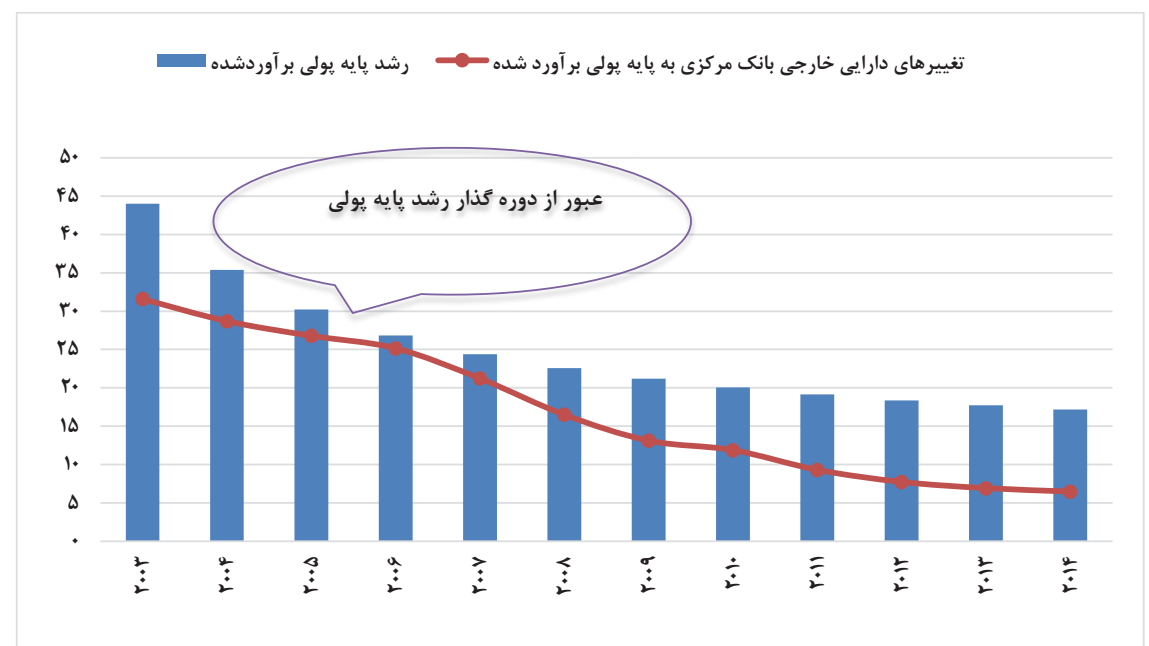

نمودار با ا: رشد پايه يولى و تغييرهاى خالص دارايىهاى خارجى به پايه يولى بر آوردشده (درصد)

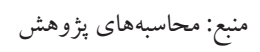

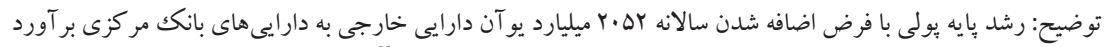

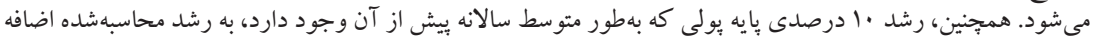

$$
\text { مىشود. }
$$

بنابراين، بانك مركزى با اين برآورد، بايد دوره كذار را كه در آن نرخ رشد پايه يولى مىتواند در اثر

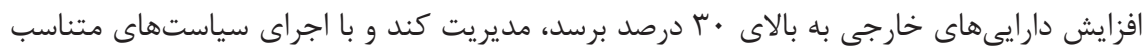
يولى، نرخ تورم را در اين دوره كنترل كند. يس از دوره گذار، ميزان تغييرهاى خالص داريىهاى

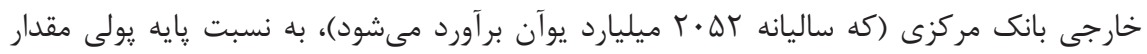

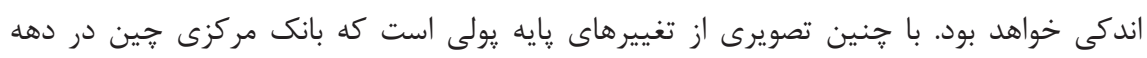

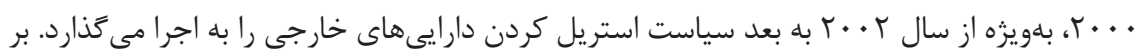


اساس اين سياست، در حالى كه افزايش خالص دارايى هاى خارجى بانك مركزى موجب رشد ترازئ مازنامه

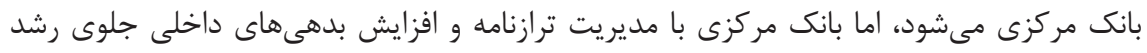

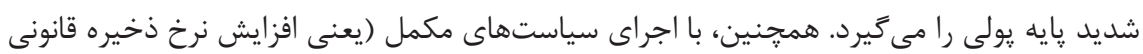

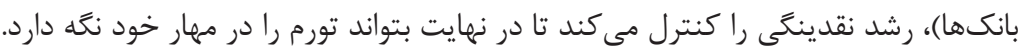

ورود مازاد تراز يرداختها به دارايىهاى خارجى بانك مركزى باعث رشد دارايىهاى خارجى

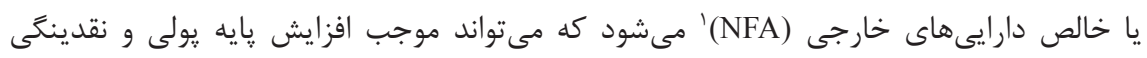
شود. استريل كردن دارايىهاى خارجى به اين معناست كه همزمان كه خالص دارايى هايى هاى خارجى

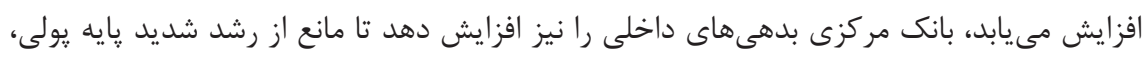

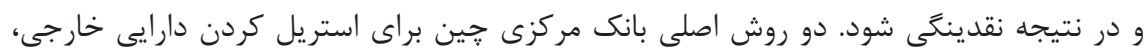

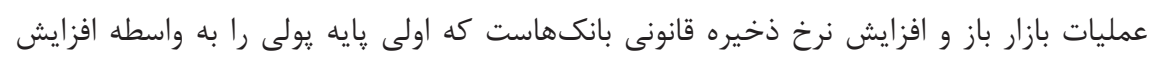
بدهىهاى داخلى (كاهش دارايىهاى داخلى) كاهش مى دهد و در نهايت، بر نقدينكى اثر دارد و

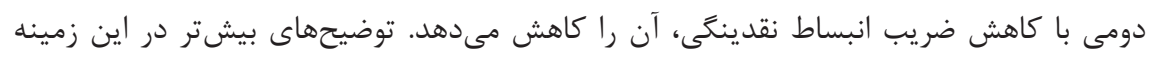
در جدول (1) آمده است. 
جدول ا: ابزارهاى سياست يولى استريلشده در جين

\begin{tabular}{|c|c|}
\hline فرايند & روش \\
\hline 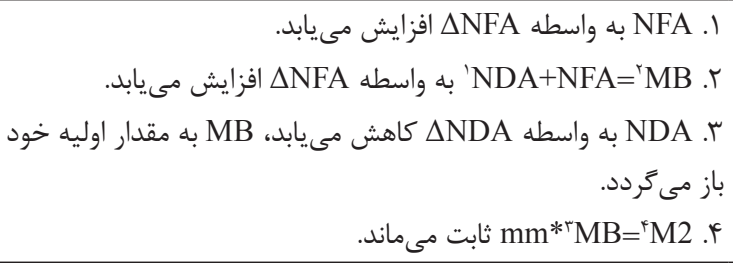 & 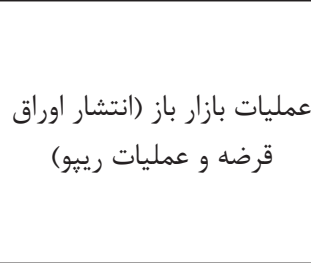 \\
\hline 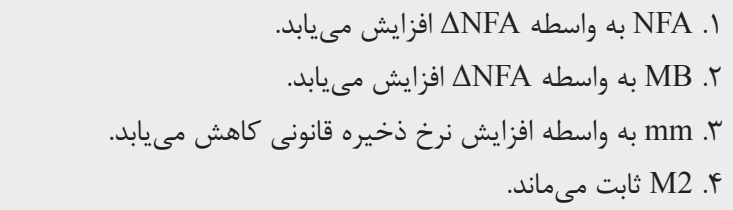 & افزايش نرخ ذخيره قانونى \\
\hline
\end{tabular}

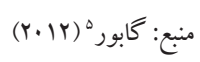

عمليات بازار باز

بانك مركزى حين عمليات بازار باز را با استفاده از خريد و فروش اين سه ابزار انجام مىدهد: اوراق

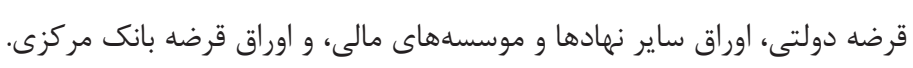

اوراق قرضه دولتى

بانك مركزى حين تا ِيش از سال ץ. • ب از اوراق قرضه دولتى براى عمليات بازار باز استفاده مى كند.

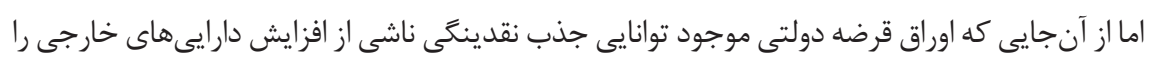

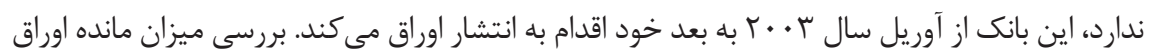

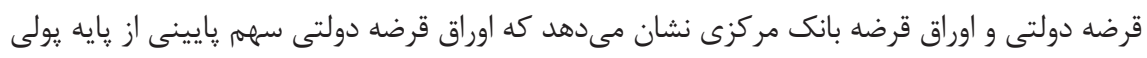

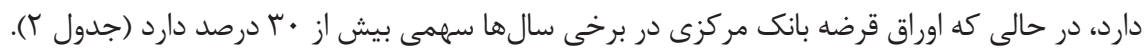

(. Iالص دارايى داخلى (Net Domestic Asset)

r. بايه پولى (Monetary Base)

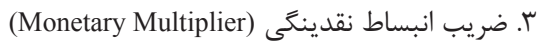

5. Gábor 
جدول ז: اوراق قرضه دولتى و بانك مركزى

\begin{tabular}{|c|c|c|c|c|c|}
\hline نسبت ماند اوراق بانكى به هايد & $\begin{array}{l}\text { مانده اوراق بانك مركى } \\
\text { ميليارد يوآن) }\end{array}$ & بهبت ماوراق دولتهى & ״ايه يولى & (ميليارد يو دولتى آنى آن & سال \\
\hline$r \Delta /{ }^{\alpha} r$ & $F \Delta V V / q \Lambda$ & .194 & ITqTr/Tr & $\Lambda \cdot / \cdot \cdot$ & $r \cdots \wedge$ \\
\hline$r q / r)$ & FT.G/FT & . 1 Kr & IFrqA/D. & $\mid r \cdot 1 \cdot$ & $r \cdots q$ \\
\hline$T I / A \Delta$ & $r \cdot r q / V r$ & $\cdot \mid \Lambda 9$ & $|\wedge \Delta K| /||$ & $19 \cdot 1 \cdot \cdot$ & $r \cdot 1$. \\
\hline $1 \cdot / 4 q$ & TrMT/gV & $1 / \pi 9$ & TYYGF/IA & $r q \cdot / \cdot$ & $r \cdot 11$ \\
\hline$\Delta / \Delta \cdot$ & $\| r \wedge \Lambda /$. & - & TATMYIDT & - & $r \cdot 1 r$ \\
\hline ケ/^६ & $V V G / T$. & $\cdot|f|$ & $r V I \cdot r / T I$ & $11 \cdot 1 \cdot$ & $r \cdot 1 r$ \\
\hline
\end{tabular}

منبع: گززارش سياست يولى جين سالهاى مختلف' و ترازنامه بانكك مر كزى جين در سالهاى مختلف' '

\section{اوراق ساير نهادها و موسسههاى مالى}

خريد و فروش اوراق ساير نهادها و موسسههاى مالى در صورتى كه به صورت رييوّ باشد، بانك مركزى در نقش فروشنده دارايى و قرض

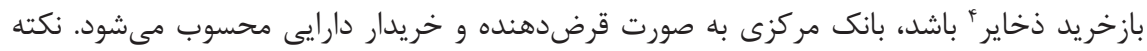

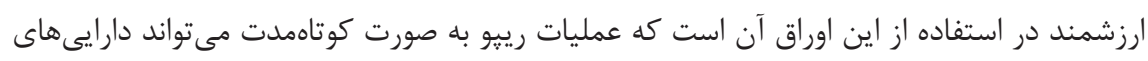
تزريقشده ناشى از افزايش دارايى هاى خارجى را جذب كند و بانك مركزى نيز عمليات رييو راس براى إنى

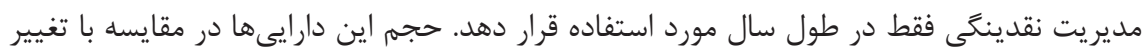
ذخاير خارجى بانك مركزى اندك است. يس اين ابزار نيز نقش اصلى را در سياست استريل كردن

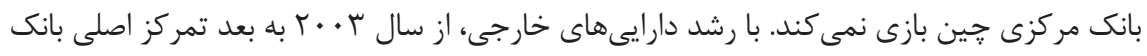

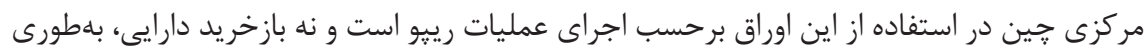

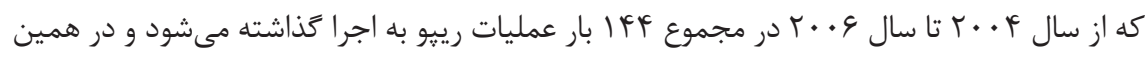

بازه زمانى تنها ه بار عمليات بازخريد دارايى انجام مىشود (Geiger, 2008).

1. China Monetary Policy Report

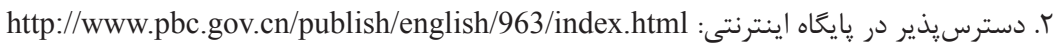




\section{اوراق قرضه بانك مر كزى}

اجراى عمليات بازار باز از راه انتشار و خريد و فروش اوراق قرضه بانك مركزى مهمترين سياست

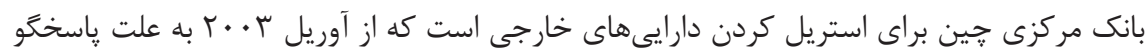
نبودن اوراق قرضه دولتى و عمليات رييو به اجرا حذاشته مىشود. اوراق قرضه سهماهه و اوراق قرضه يكساله بيشترين سهم را از اوراق قرضه منتشرشده توسط بانك مركزى جين دارند. اوراق ششماهد

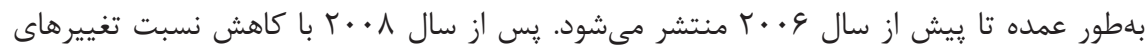

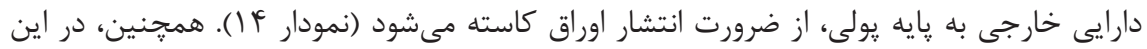
سال با توجه به كاهش نرخ بهره در آمريكا هزينه انتشار اوراق قرضه براى بانك مركزى جين افزايش مىيابد، زيرا دارايىهاى خارجى جين كه به صورت اسناد خزانه آمريكا و ساير اوراق آمريكايى است،

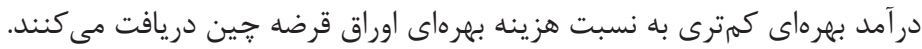

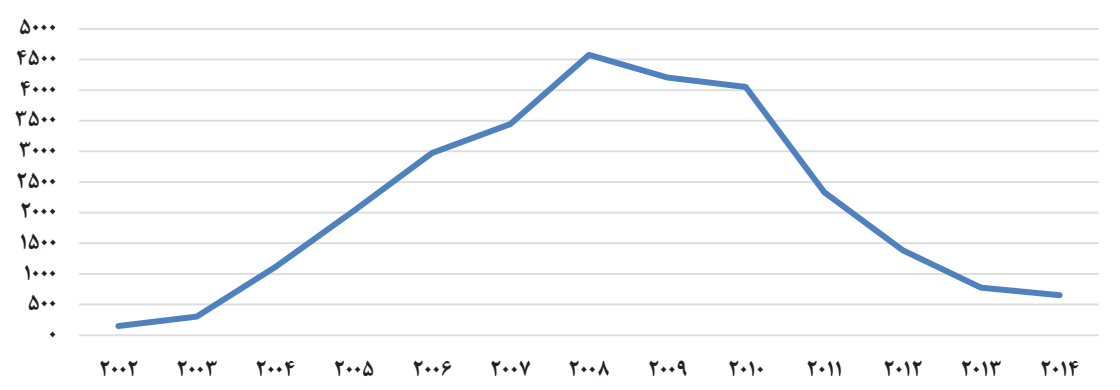

نمودار † ا: مانده اوراق قرضه بانك مر كزى جين (ميليارد يوآن)

منبع: ترازنامه بانكك مر كزى خين مئن

در بالا اشاره شد كه مسئله بانك مركزى جين براى استريل كردن دارايىهاى خارجى مديريت

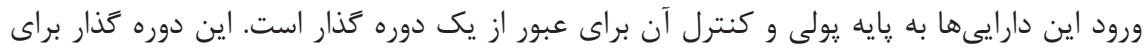

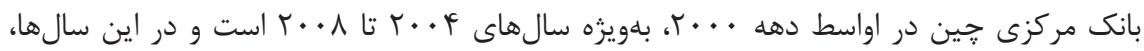
بانك مركزى جين درصد بالايى از دارايى هاى خارجى را به واسطه انتشار اوراق قرضه استريل مرى كند. 


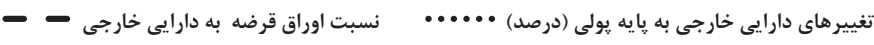

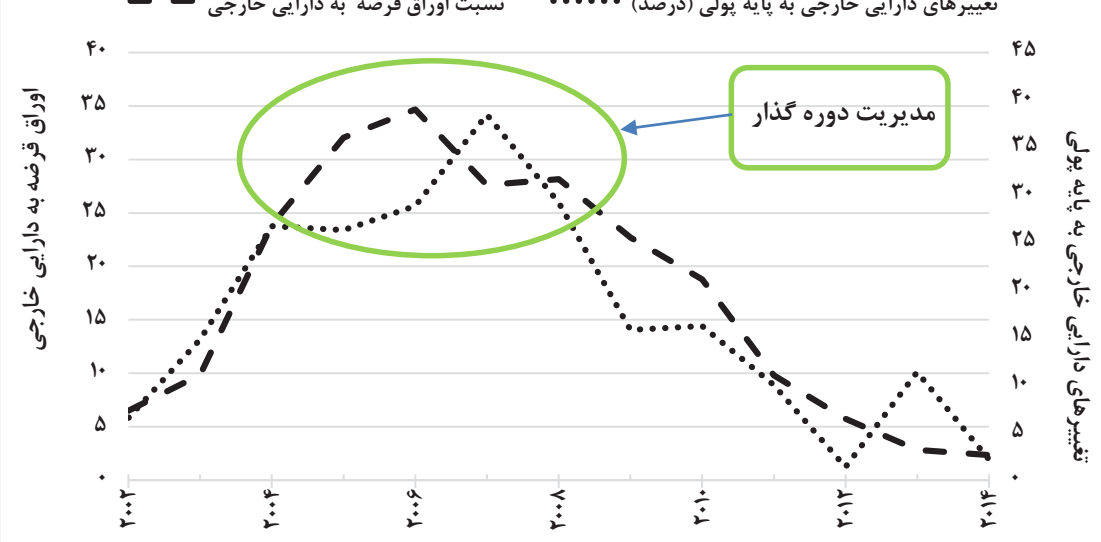

نمودار ها: نسبت اوراق قرضه بانك مر كزى به دارايىهاى خارجى و تغييرهاى دارايىهاى خارجى به هايه يولى (درصد)

منبع: ترازنامه بانكك مركزى خين (دوصائ

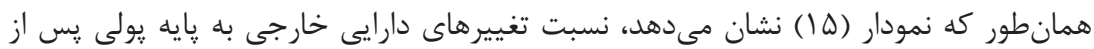

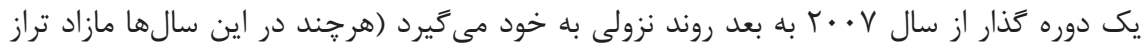

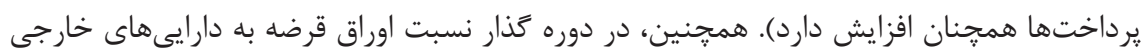

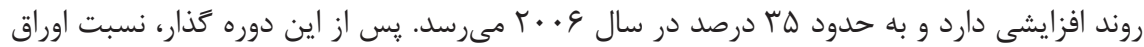

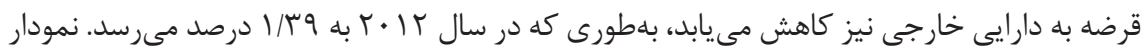
(ه ()، مديريت ترازنامهاى بانك مركزى را براى افزايش بدهى هاى داخلى در دوره حَذار بهخوبى نشان

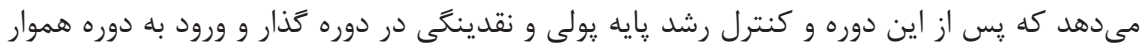

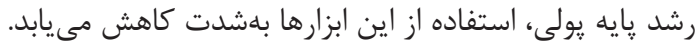

\section{نرخ ذخيره قانونى بانكها}

بانك مركزى جين با افزايش نرخ ذخيره قانونى، منابع بانكها را براى اعطاى وام كاهش مى دهد 
مركزى جين از مارس 1991 تا مارس r| • ب نرخ ذخيره قانونى را أ| بار تعديل مى كند. از اين ميان تنها هفتبار نرخ ذخيره قانونى كاهش مى يابد كه آن هم در دوره بحران مالى آسيا (1991) (19)، بحران

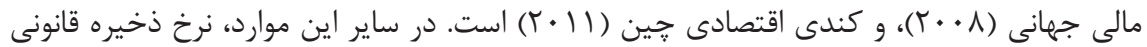

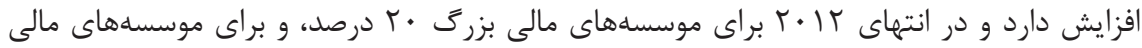

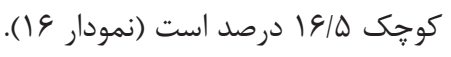

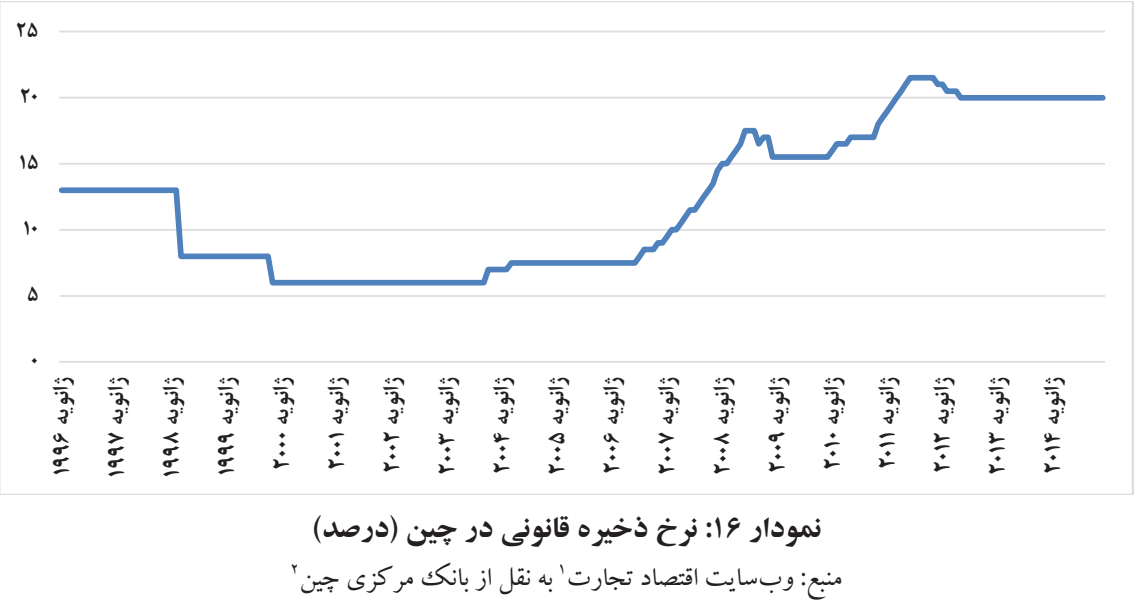

نرخ ذخيره قانونى بالا در جين (بهطورى كه تا پيش از كاهش اخير در نرخ ذخيره قانونى، جين با

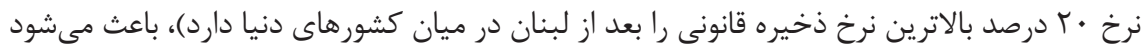

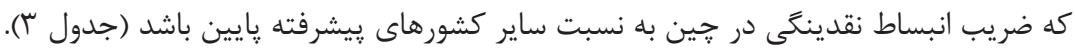




\begin{tabular}{|c|c|c|c|}
\hline ضريب انبساط نقدينَى & كشور & ضريب انبساط نقدينكى & كشور \\
\hline$r / \mathbb{F}$ & جين & G/VT & ايالات متحده آمريكا \\
\hline$p / 19$ & هند & $9 / 94$ & زاين \\
\hline p/gt & تر كيه & $r \cdot / r \Lambda$ & كانادا \\
\hline$D / T H$ & عربستان سعودى & $r \cdot / r v$ & 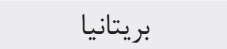 \\
\hline$\Delta / 91$ & برزيل & $r \cdot 191$ & 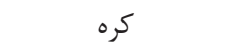 \\
\hline
\end{tabular}

منبع: محاسبهاى بُزوهش بر اساس دادههاى شاخصهاى اصلى جهانى صندوق بين المللى يول' برزل

بانكى مركزى حين با استفاده از دو روش بالا مىتواند با موفقيت از دوره كذار عبور كند و به رشد

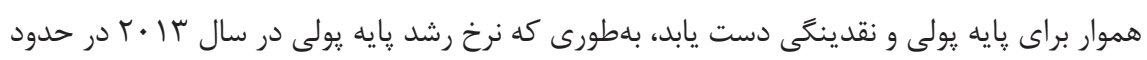
V درصد است.

\section{جالشهاى استريل كردن}

به نظر مىرسد كه بانك مركزى جين مىتواند با اجراى سياست استريل كردن دارايىهاى خارجى، بازار ارز و نرخ تورم را كنترل كند و به اهداف تعيينشده در اين زمينه دست يابد. باند اين اين حال،

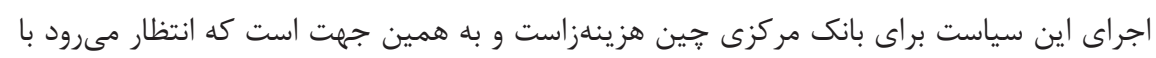

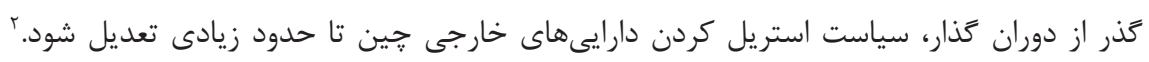

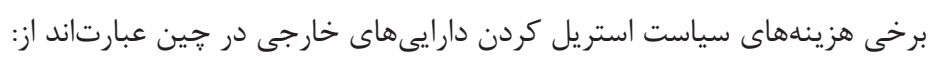

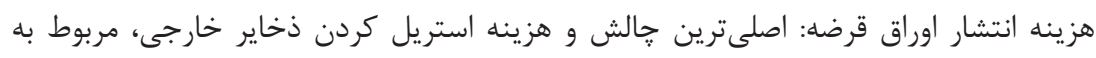

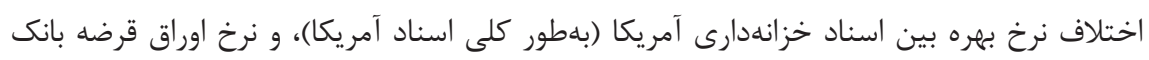

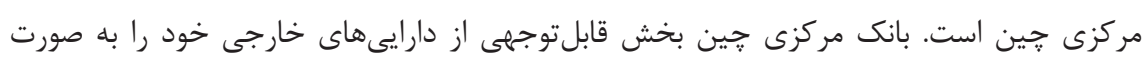

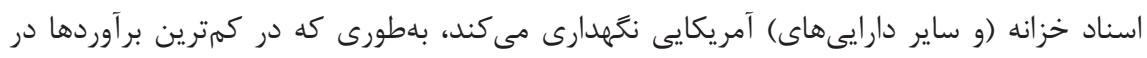

1. Principal Global Indicators (http://www.principalglobalindicators.org/Pages/Default.aspx) r. روند بكارگيرى ابزارهاى بانك مركزى جين براى سياست استريل كردن نيز تعديل نسبى اين سياست را نشان

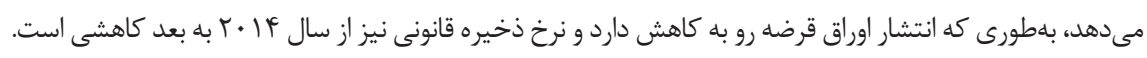




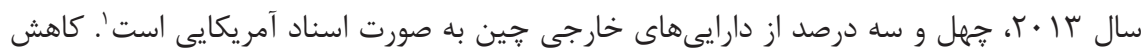
نرخ بهره در آمريكا باعث مىشود كه نرخ بهره يرداختى توسط بانك مركزى جين بيش از نرخ بهره

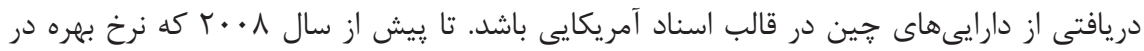
آمريكا كاهش ندارد، نرخ اسناد خزانه بيش از نرخ اوراق قرضه جين است و جين از اين سياست نفع ميبرد. اما پِ از آن، اين سياست به ضرر جين است، بهطورى كه اختلاف بين نرخ اسناد سهماهه در

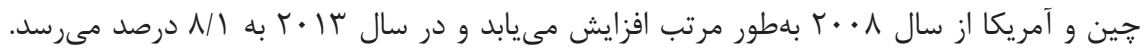

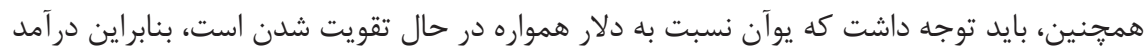

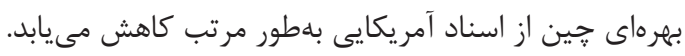

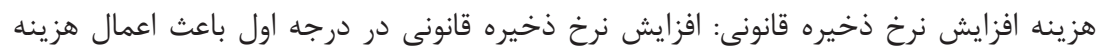

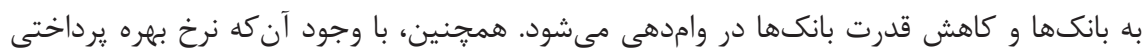

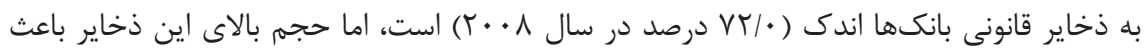
مىشود كه افزايش ذخاير قانونى بانكها براى بانك مركزى نيز هزينهزا باشد.

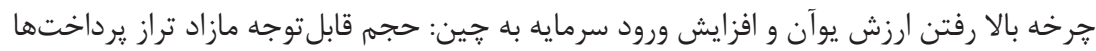

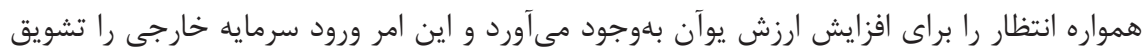

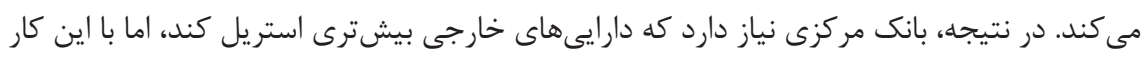
هزينههايش دوباره افزايش مى ميابد.

\section{بحث و نتيجه كيرى}

اين يزوهش، با هدف معرفى راهكارى براى دستيابى همزمان به دو هدف حفظ رقابتيذيرى توليد داخلى و كنترل تورم در شرايط وفور درآمدهاى ارزى، به بررسى تجربه جين درى دراين اين زمينه

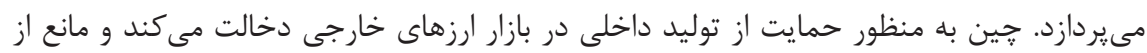

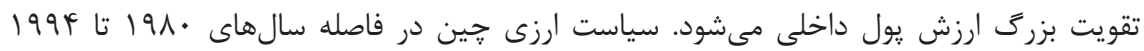

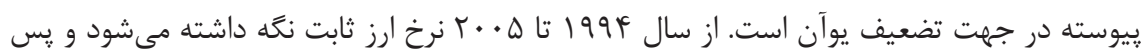
از آن، بهجز در برخى موارد، يوآن نسبت به دلار به صورت تدريجى تقويت مى شود. دخالت جين در

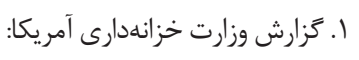

U.S. Treasury Department Report on Foreign Portfolio Holdings of U.S. Securities, 2013 https://www.treasury.gov/press-center/press-releases/Pages/tg1557.aspx دسترسيذير در: 
بازار ارزهاى خارجى و بسته بودن نسبى حساب سرمايه، موجب حجم بالاى مازاد تراز يرداختها

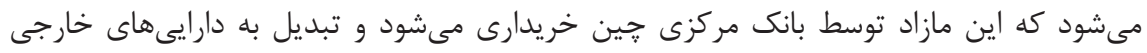

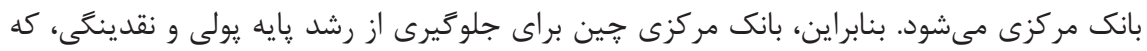
به تورم منجر مىشود، سياست استريل كردن دار ايىهاى خارجى را اجرا مى كند. بانك مركزى جرين با اجراى سياست استريل كردن دارايىهاى خارجى از راه انتشار اوراق قرضه و افزايش نرخ ذائى ذخيره

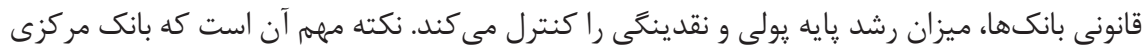

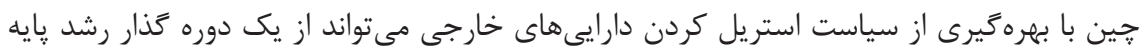

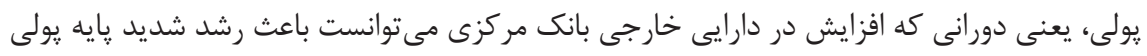

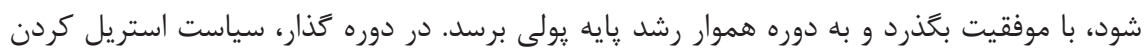

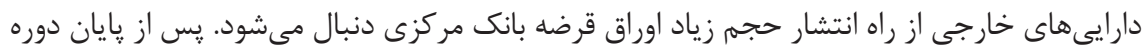
كذار، رشد اوراق منتشرشده توسط بانك مر كزى بهشدت كاهش بيدا مى كند و نرخ ذخيره قانونى نيز

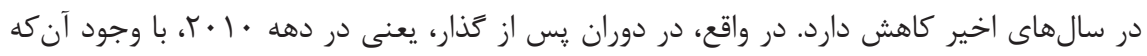

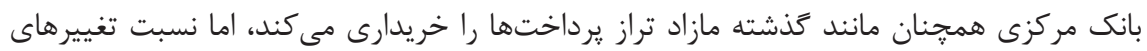

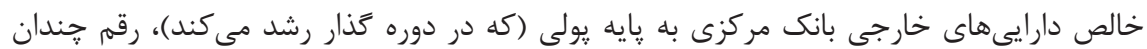
بالايى نيست و رشد شديد پايه يولى را در يى ندارد.

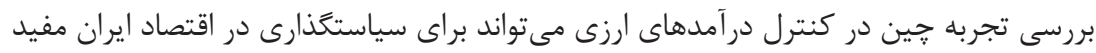

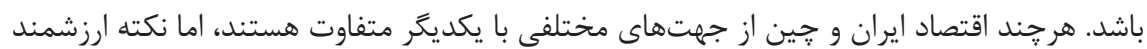
در استفاده از تجربه جين در كنترل درآمدهاى ارزى آن است كه بانك مركزى جين از دو دو ابزار انتشار اوراق قرضه بانك مركزى و نرخ ذخيره قانونى استفاده مى كند و بانك مركزى ايران نيز تجربه استفاده

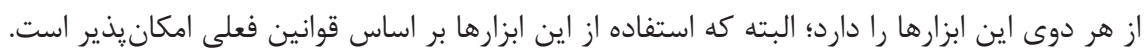
فقدان بازارهاى مالى فعال و حجم كوجى بازار ثانويه براى اوراق قرضه دولتى در ايران امكان اجراى برى برى سياست يولى همانند بانكهاى مركزى در كشورهاى توسعهيافته را با مشكل مواجه مى كند. بنابراين،

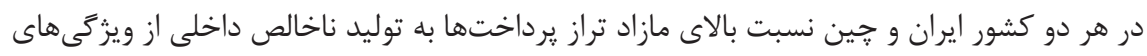

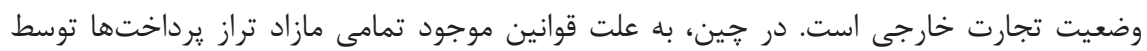
بانك مركزى خريدارى مىشود و در ايران نيز به علت آن كه سهم دولت از درآمدهاى ارزى بالاست،

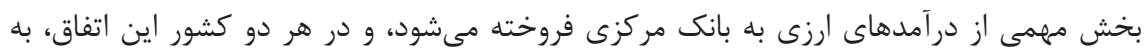

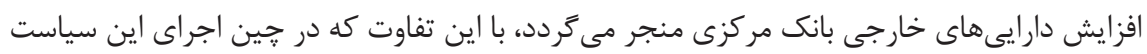




$$
\begin{aligned}
& \text { در جلوكيرى از تضعيف رقابتيذيرى توليدهاى داخلى موفق است. علاوه بر آن، بانك مركزى جين با }
\end{aligned}
$$

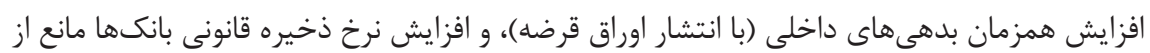

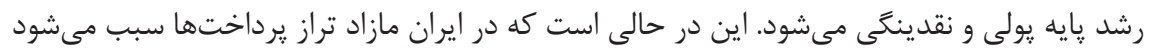

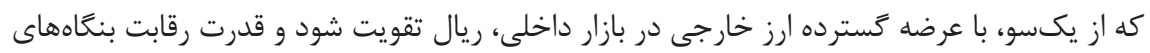

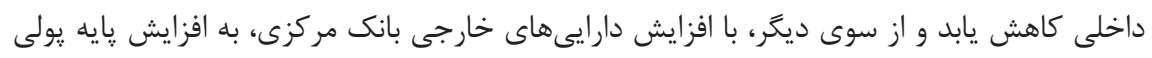

$$
\begin{aligned}
& \text { و افزايش تورم منجر شود. }
\end{aligned}
$$

Gábor, T. (2012). China's Monetary Sterilization and its Economical Relationship with the European Union. Paper Presented at the Crisis Aftermath: Economic Policy Changes in the EU and its Member States, International Conference Proceedings.

Geiger, M. (2008). Instruments of Monetary Policy in China and their Effectiveness: 19942006. UNCTAD Discussion Paper No. 187.

Goldstein, M., \& Lardy, N. R. (2009). The Future of China's Exchange Rate Policy (Vol. 87): Peterson Institute for International Economics.

Goujon, M., \& Guérineau, S. (2006). The Modification of the Chinese Exchange Rate Policy. Its Rationale, Extent and Recent Developments. China Perspectives, 64(1), 1-15.

Marin, Y. (2009). Chinese Sovereign Wealth Funds: Past, Present and Future. Revue d'Économie Financière, Special issue, 105-114.

Martin, M. F. (2010). China's Sovereign Wealth Fund: Developments and Policy Implications. CRS Report for Congress R41441: Congressional Research Service, Washington DC. 